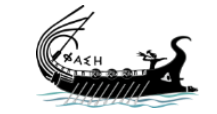

journal.phaselis.org
PHAS LLIS

Issue IV (2018)
Disiplinlerarası Akdeniz Araştırmaları Dergisi

Journal of Interdisciplinary Mediterranean Studies

\title{
Phaselis ve Teritoryumunun Yol ve Savunma \\ Sistemleri: Tekirova-Çamyuva Arası
}

Road and Defence Systems of Phaselis and its Territorium:

Between Tekirova- Çamyuva

\section{Murat ARSLAN}

open access journals

The entire contents of this journal, Phaselis: Journal of Interdisciplinary Mediterranean Studies, is open to users and it is an 'open access' journal. Users are able to read the full texts, to download, to copy, print and distribute without obtaining the permission of the editor and author(s). However, all references to the articles published in the e-journal Phaselis are to indicate through reference the source of the citation from this journal.

Phaselis: Journal of Interdisciplinary Mediterranean Studies is a peer-reviewed journal and the articles which have had their peer reviewing process completed will be published on the web-site (journal.phaselis.org) in the year of the journal's issue (e.g. Issue III: JanuaryDecember 2017). At the end of December 2016 the year's issue is completed and Volume IV: January-December 2018 will begin.

Responsibility for the articles published in this journal remains with the authors.

Citation M. Arslan, "Phaselis ve Teritoryumunun Yol ve Savunma Sistemleri: Tekirova-Çamyuva Arası". Phaselis IV (2018) 15-46. http://dx.doi.org/10.18367/Pha.18002

Received Date: 06.01.2018 | Acceptance Date: 12.01.2018

Online Publication Date: 13.02.2018

Phaselis Research Project

www.phaselis.org 


\title{
Phaselis ve Teritoryumunun Yol ve Savunma Sistemleri: Tekirova-Çamyuva Arası
}

\author{
Road and Defence Systems of Phaselis and its Territorium: \\ Between Tekirova- Çamyuva
}

\author{
Murat ARSLAN*
}

\begin{abstract}
Öz: Bu makalenin amacı Phaselis ve hinterlandında (Tekirova-Çamyuva arası) 2012 yılından itibaren gerçekleştirilen disiplinlerarası yüzey araştırmaları kapsamında kentin yakın çevresindeki mahalleler ve komşu yerleşimler ile Lykia ve Pamphylia bölgeleriyle bağlantısını sağlayan ulaşım ve savunma sistemlerini tespit etmeye çalı̧arak bunları tipolojik ve dönemsel olarak sınıflandırmaktır. Bu bağlamda öncelikli olarak kentin teritoryumuyla olan girift ilişkisini sağlayan kompleks ulaşım sisteminin tespiti, belgelenmesi, gps koordinatlarının alınarak envanterlenmesi yapıldıktan sonra yol ağının ortaya çıkartılması ve topografik haritaya işlenmesi hedeflenmiştir. Kentin savunma sistemlerinin çeşitleri incelenirken ise, yerleşimin yayıldığı mekan ve çevreyle olan ilişkisinin çok yönlü araştırmalarla irdelenmesine, Phaselis hinterlandında yer alan tahkimli yerleşimler [kentçik (polikhnikon); köy (kome)], surlar, kuleler ve gözetleme kulelerinin lokalizasyonlarının arazi çalışmalarıyla belirlenmesine odaklanılmışır. Makalenin kuramsal yaklaşımı/yöntemi core (centrum/merkez) ve periphery (çevre/hinterlant) teorisine dayanmaktadır. Diğer bir deyişle konsantrik daireler şeklinde kentin merkezinden ardalanına doğru ilerleyen ulaşım ve savunma sistemine yönelik difüzyon ağı çok yönlü şekilde mercek altına alınmıştır. Bunu yaparken yol sistemiyle bağlantılı Phaselis'in yerleşim ve alan arkeolojisine dair disiplinlerarası çok yönlü-kontrol edilebilir yeni verilerin bilinir klınmasına ve yol güzergahlarıyla ilişkilendirilmesine çalışılmışıı.
\end{abstract}

Anahtar sözcükler: Phaselis, Yol Sistemleri, Savunma Sistemleri, Alan Arkeolojisi

Abstract: This article aims to locate the road and defense systems between the city of Phaselis and in its immediate vicinity together with the regions of Lycia and Pamphylia, and to classify them both typologically and cyclically. This research has been undertaken within the scope of the interdisciplinary field surveys conducted at Phaselis and within its hinterland (between Tekirova and Çamyuva) since 2012. Within this context, the aim was to determine and document the complex road system that provides an intricate web of interrelationship of access between the city and its territory; to define the road network through inventory with GPS coordinates, and to add it to the topographic map. Combined with the analysis of the city's defense systems, it is also focused on studying the relationship between the urban settlement and its surroundings through multi-directional investigations, and determining the context and localizations of the fortified settlements, such as small city (polikhnikon), town (kome), walls, towers and watchtowers located in the hinterland of Phaselis through these field surveys. The theoretic approach employed in this article hinges on the theory of core (centrum) and periphery (environment/hinterland). In other words, the access-diffusion network for the transport and defense system, moving in succession from the center of the city in the form of concentric circles, has been examined in a multifaceted way. In doing so, this article also presents the new multidisciplinary verifiable data concerning the settlement and field archeology of Phaselis relating to the road system, identifies these structures and relates them to the itineraries.

Keywords: Phaselis, Road Systems, Defence Systems, Landscape Archaeology

* Prof. Dr., Akdeniz Üniversitesi, Edebiyat Fakültesi, Tarih Bölümü, Antalya, marslan@akdeniz.edu.tr Burada sunulan çalışma Akdeniz Üniversitesi, Bilimsel Araştırmalar Koordinasyon Birimi tarafından SAY-2015874 no'lu proje kapsamında desteklenmiştir. 
Periplus'ların (seyr-ü sefer) uzakları yakın etmesi ve belli rotalar üzerinde deniz seyrine elverişli mevsimlerde rüzgar gücüyle hızlı şekilde uzun mesafeler kat edilebilmesi antikçağ ticaretine denizciliğin damgasını vurmasını sağlamıştır. Bronz Çağı'ndan itibaren gemi teknolojisindeki gelişmelere paralel olarak antikitenin ana ticaret rotaları Doğu Akdeniz'de yelken açan büyük yük ve kargo gemileri vasıtasıyla yapılmaktaydı. Kültürlerarası iletişim ve etkileşimin giderek artması Demir Çă̆ı'nda da deniz ticaretinin yaygınlaşmasına ve dolayısıyla sahil/ada kentlerinin ekonomik açıdan zenginleşmesine yol açmaktaydı. Bu durum sahil kentlerini bir yandan emporion [potansiyel iş merkezi] haline dönüştürürken diğer yandan halkın refah seviyesinin yükselmesini, kentlerin kültür ve cazibe merkezi haline gelmesini sağladı. Öyle ki, antikitede "zenginlik denizden gelir" ifadesi anlamını buldu. Bu bakımdan günümüzde olduğu üzere antikçağda da Akdeniz havzasında yaşayan nüfusun büyük bir bölümü çekim merkezleri olan sahil kentlerinde ya da hinterlantlarında ikamet etmeye başladı. Dolayısıyla demografik açıdan çeşitlilik gösteren yoğun nüfuslu kentler ya ticaret rotası üzerinde elverişli limanlarda; mendireklere korunan güvenli demir atma ve yük indirme bindirme alanlarına sahip kıyılarda ya da sahille bağlantısı olan nehir güzergahları üzerinde yer almaktaydı. Phaselis de gemilerin yanaşmasına, demir atmasına ve güvenli bir şekilde yük indirip bindirmesine olanak sağlayan birbirinden elverişli üç limanı, lagünü ve mendirekleriyle bu ticaretten bilindiği kadarıyla Arkaik Dönem'den itibaren önemli oranda pay aldı. Bu durum kendini kentin darp ettiği sikkelerden, taşınmaz kültür varlıklarına, seramolojiden epigrafik belgelere ve arkeolojik materyal kalıntılarına kadar eskiçağ tarihini kendine konu edinen her disiplinde gösterdi ${ }^{1}$.

Konu Doğu Akdeniz ve Lykia ile Pamphylia sınırındaki bağımsız bir sahil kentinin (Phaselis) yol ve savunma sistemlerini araştırmak olunca yerleşime yüksek oranda ithal edilen malzemenin sikke karşıığı alınıp satılması kadar emtia değiş-tokuşunu, kentin ihracat hacmini ve potansiyelini göz önünde bulundurmak gerekir. Antikitede sahil kentleri sürekli göç alarak bir yandan demografik yapılarını çeşitlendirirken diğer yandan da adeta birbirleriyle yarışırcasına güçlenip karada da hakimiyet alanlarını artırma ve diğer kent-bölgelerle kara ticaret hacimlerini genişletme çabası içindeydiler. Bunu yaparken komşu kentlerle sürekli rekabet halindeydiler. Kente ithal edilen mallar tacirler tarafından agora/forum'larda satılırken diğer yandan da kentten Phaselis'ten- hammadde, yöresel, endüstriyel ve lüks ürünler ihraç edilmekteydi. Hammadde ve yöresel ürünler kentin hakimiyet alanından sağlanırken endüstriyel ürünler genellikle kent ve yakın çevresinde üretilirdi. Kent kendi üretim fazlası ürünlerini talep doğrultusunda komşu kentler, bölgeler, adalar ve kıtalardaki yerleşimlerle değiş tokuş etmekte ve kar sağlamaktaydı.

1 Söz konusu refah düzeyi MÖ VI. yüzyıldan itibaren Phaselis'in bastığı ve Doğu Akdeniz'in değişik kentlerine ve coğrafyalarına (Mısır) değin yayılan, sikkelerine kontrmark (Side, Aspendos etc.) vurulan (Callatay 2017) ve MÖ VI.-V. yüzyıllara tarihlenen sikke hazineleriyle (Mısır: Damanhur (IGCH 1637), Benha el Asl (IGCH 1640), Zagazig (IGCH 1640; Ürdün: IGCH 1482; Asyut IGCH 1644; Rhodos IGCH 1185; Antilibanon Hurter Pásztory 1984, 111 vdd.) ön plana çıkmaktadır (Daha detaylı bilgi için ayrıca bk. Tüner Önen 2008, 5 vd.). Aynı şekilde Phaselis'te bulunan ve harf karakterinden dolayı MÖ VI. yüzyıla tarihlenen yeni bir yazıta göre de, büyük bir ihtimalle denizcilikle uğraşan Khysias oğlu Euphanes, adağını yerine getirmek için mallarının on'da birini Athena Polias'a vakfetmiştir (daha detaylı bilgi için bk. Tüner Önen-Yılmaz 2015, 121 vdd.). MÖ 475 yılına tarihlenen ve Ahikar adlı bir memur tarafından muhtemelen Naukratis'te tutulan kayıtlara ilişkin Elephantin'de bulunan papirüs belgesinden izlenebildiği üzere, Phaselis ile Mısır arasında yoğun bir ticaret ağı bulunmaktaydı. Öyle ki MÖ ca. 474 yılında 36 Phaselis gemisi Mısır’ın Naukratis (?) limanına yanaşarak kent teritoryumundan elde ettiği yüklü miktarda, şarap, zeytin yağı, işlenmiş ve işlenmemiş kereste, sedir, gemi direği ve dümeni vb. ürünleri ticaret amaçıı Mısır’a götürmüştür. Karşılığında ise, büyük ölçüde natron alarak Phaselis'e geri dönmüştür. Daha detaylı bilgi için ayrıca bk. Kuhrt 2007, 680 vdd; Atilla 2018, 72 vdd. 
Sahil kentleri açısından bu rekabet deniz kadar kara ticareti açısından da önem arz ederdi. Bu durum Immanuel Wallenstein'ın Dünya Sistem Teorisi adlı tezinden de izlenebildiği üzere, kent ve teritoryumu arasındaki yoğun iletişim ve trafik sayesinde gerçekleşmekteydi ('core' (merkez) ile 'periphery' (hinterland). Bu da merkezin (kentin) yakın çevresi ve hinterlandıyla olan ilişkisiyle açıklanmaktaydı. Yakın çevre ve hinterlantla olan bu iletişim sofistike bir yol ağıyla birbirine bağlıydı. Merkezden yakın çevreye yüksek kalite yerli ve dışarıdan gelen ithal ürünler sevk edilirken (yüksek kalite seramik, silah, şarap, sanat eserleri, parfüm etc.) yakın çevre ve hinterlanttan limanlara ve ana kente ucuz işgücü, hayvan, köle, zeytinyağı, şarap, işlenmişişlenmemiş ahşap -özellikle sedir-, kil ve madeni/metal ham maddeler gönderiliyordu. Bu ürünlerin bir kısmı kentliler tarafından tüketilirken bir kısmı ya işlenerek ya da işlenmeden çoğunlukla deniz bazen de kara yoluyla diğer kentlere ve bölgelere ithal ediliyordu.

Ana kent ile otonomisi altındaki yerleşimleri birbiriyle ilintilendiren sympoliteia gibi politik sistemlerin yanı sıra son derece komplike yol ağları bulunmaktaydı ${ }^{2}$. Yol ağları Phaselis'i besleyen ana damarlar olup kentle doğrudan ya da dolaylı -tarımsal, ekonomik, sosyal, politik ve askeri anlamda- şekillerde irtibat içindeydi. Bu yüzden antikçağ sahil kentlerini gerektiği gibi anlamak ve yorumlamak için kentleri teritoryumlarıyla birlikte diğer kent, bölge, kralıılarla olan münasebetlerini zamandizinsel bir perspektif içinde çok boyutlu değerlendirmek gerekir ${ }^{3}$.

Phaselis 19. yüzyılın ilk çeyreğinden 20. yüzyılın sonlarına değin farklı özelliklerinden ötürü münferit intervallerle birçok farklı disipline ait bilim insanının ilgisini çekmiş görünür. Ancak son iki asırda araştırmacıların uzmanlık alanları özelinde kente olan ilgileri değişik nedenlerden ötürü uzun soluklu olmamıştır ${ }^{4}$. Kentin yakın hinterlandına ve teritoryumuna (periferi) yönelik araştırmalar ise, kısa süreliğine Beydağları Araştırmaları kapsamında Akdeniz Üniversitesi'nden Doç. Dr. İsa Kızgut ${ }^{5}$ ile Stadiasmos Araştırmaları sırasında rahmetli hocam Prof. Dr. Sencer Şahin ve ekibi tarafından gerçekleştirilmiştir ${ }^{6}$. Bununla birlikte 2012 yılından itibaren Phaselis ve teritoryumunda yürütülen disiplinlerarası çalışmalar, Phaselis hinterlandının şimdiye kadar bilinen ve tahmin edilenin ötesinde, son derece yoğun iskan ve yol ağına sahip olduğu sonucunu ortaya çıkarmışıı?.

Phaselis'in kesin bir şekilde Arkaik Dönem'den itibaren teritoryumuyla bağlantısını sağlayan yol güzergahlarına sahip olduğu varsayılabilir. Bu ağın, Klasik Dönem'de iki asırdan fazla Pers hakimiyetinde kalan bölgeyi etkileyen kısa süreli çarpışmalar ve ayaklanmalar sayılmazsa, uzun süreli barış ortamı altında giderek artan refah seviyesine paralel gelişerek çeşitlendiği ve geliştiği düşünülebilir. Zira kentin stratejik konumu itibariyle diğer kentler ve Lykia, Pamphylia ve Pisidia gibi komşu bölgelerle ilişkisi göz ardı edilemeyecek derecede önemlidir. Gene de bu durum antikçağın temel ve hızlı ulaşım ağının deniz rotaları üzerinden gerçekleştirildiği gerçeğini göz

2 Her ne kadar antikçağda da Phaselis ticari hacminin ca. \% 90'ına yakınını deniz ticaretinden elde etse de kentin gerek hinterlandıyla gerekse iç bölgelerdeki kentlerle ulaşım ve iletişim ağını sağlayan ve teritoryumunu adeta bir örümcek ağı gibi ören yoğun bir yol sistemine sahip olduğu ifade edilebilir.

3 Bu yönden bakıldığında ve günümüze kadarki Phaselis çalışmaları incelendiğinde bunların hemen hemen tamamının kentin tam anlamıyla merkezine (core) yönelik olduğu görülecektir. Bunlar kendi içinde kentin ticari (liman ve liman yapıları, agora'lar), kamusal (tiyatro, hamamlar, ana cadde, Hadrianus kapısı) ve dini (tapınaklar, kiliseler) yapıları olmak üzere üç başlıkta sınıflandırılabilir.

Phaselis'in kent araştırma birikimine ilişin detaylı bilgi için ayrıca bk. Arslan - Tüner Önen 2014, 78 vdd.

Kızgut, 2017, 199 vdd.

Stadiasmus Patarensis - ITINERA ROMANA PROVINCIAE LYCIAE - Likya Eyaleti Roma Yolları (2014).

Phaselis antik kenti ve teritoryumu yüzey araştırma raporları AST XXXI vdd. (2014-) ve Anmed XI vdd. (2013). 
ardı ettirmez. Zira Karyandalı Skylaks'a (100) göre, [Karia] ile Pamphylia arasında kara güzergahının dağıık topografyası ve körfezler nedeniyle izlenecek yol güzergahı seyr-ü sefer edilirken izlenecek rotadan iki misli fazladır. Gene de antikçağda egemenlik ve otonomi esas itibarıyla kara savaşlarıyla belirlenir. Perslerin karşısında muhtemel bir deniz savaşında hiçbir şansı olmadığını kavrayan İskender de bu sebeple ataları gibi bütün umudunu bir kara muharebesine bağlar. Bu yüzden donanmasını dağıtııtan kısa süre sonra MÖ 334 yılııın sonunda Karia üzerinden Lykia'ya yürür.

Antik kaynaklar aracılığıyla doğrulandığı üzere Phaselis'ten Klasik ve Hellenistik dönemlerde Lykia, Pamphylia ve Pisidia'ya doğru ilerleyen yol güzergahları yer almaktaydı. Zira İskender de Tlos üzerinden Kınık Vadisi'ne girdiğinde güzergahı üzerindeki Pınara, Ksanthos ve Patara'yla birlikte 30 kadar polismata'yı (kentçik) ele geçirdi ${ }^{8}$. MÖ 333 yılı kışında Milyas Bölgesi'ndeyken ona altın bir taç ve dostluk teklifleri getiren Phaselisliler tarafından karşılanarak ordusuyla birlikte Phaselis'e geldi. MÖ 333 yılının muhtemelen Şubat ayını kentte geçirdi. Bu arada Pisidialıların bölgeye gözdağı olarak kurmuş oldukları ve Phaselislileri ve teritorumundaki çiftçileri rahatsız eden, mahsüle büyük zarar veren Marmaralıları, tahkimli Mnara (Kavak Dağı) kalesinde kuşatarak ele geçirmiş burayı tahrip etmişti ${ }^{9}$. Phaselis'te birliklerini ikiye bölerek birliklerinin büyük bir çoğunluğunu Trakyalıların Klimaks ${ }^{10}$ (merdiven) denilen bir yolu yer yer basamaklar şeklinde inşa ederek Pisidia üzerinden Perge'ye (Aksu) doğru ilerlemelerini emretti. Kendisi ise kurmayları ve az sayıda askerleriyle Phaselis'ten Perge'ye doğru ilerleyen sahil yolunu izledi ${ }^{11}$.

Roma Dönemi'nde epigrafik belgeler aracılığıyla Hellenistik Dönem'de kullanılan yol ağının genişletilerek Lykia kentlerinin yanı sıra Anadolu'nun diğer Roma eyaletleriyle bağlantısını sağlayan son derece etkili bir kara ulaşım sistemiyle donatılığı ortaya çıkartılmıştır. Imparator Claudius'un Lykia'ya atadığı ilk vali Quintus Veranius MS ca. 43-44 yılında öncelikle Kaunos [Dalyan]'dan Attaleia [Antalya]'ya kadar bütün yerleşimleri ölçtürerek Lykia kentlerinin her birini diğerine kapsamlı bir yol ağıyla bağlamıştır. Patara'dan ele geçen ve Stadiasmus Patarensis şeklinde adlandırılan yol kılavuz anıtında Lykia'nın Roma İmparatorluk Çağı'nda olağanüstü sık ve

Arr. anab. I. 24. 4; kralın Ksanthos üzerinden yürüdüğüne ilişkin olarak ayrıca bk. Plut. Aleks. XVII. 3.

Arr. anab. I. 24. 3-6; ayrıca bk. Diod. XVII. 28. 1-5.

10 Onomastik olarak Hellence 'merdiven' anlamında kullanılmıştır. Burası günümüzde Ağva çayının aktığı Kesme Boğazı olarak adlandırılan kısma inşa edilmiş olabilir. Ya da daha geniş anlamda günümüzde Gavuryolu olarak adlandırılan, Beldibi ile Antalya arasında sahile paralel olarak uzanan ve yer yer denize dik inen Sarıçınar Dağı’nın güney ve kuzeydoğu uzantılarının eteklerinde katıntılarına rastlanan güzergahtır. Klimaks'a ait kalıntıların bir kısmını günümüzde Sıçan Adası'nın karşısına düşen modern otobanın hemen kenarından yükselen dik yamaç üzerinde izlemek mümkündür. Dağlara merdiven şeklinde ilerleyen bu güzergahın bir kısmı, İskender Phaselis'teyken, kent halkının isteğiyle Mnaralılara karşı cezalandırma hareketi düzenlediği sırada ordusunun hızlı yürüyüş yapması amacıyla ordusundan Agriganlar, Thrakyalılar ve hafif silahlı askerlerine inşa ettirilmişti. Konuya ilişkin olarak ayrıca bk. Şahin 2014, 101; 302 vd.; 414.

11 Plut. Aleks. XVII. 8; ayrıca bk. Strab. XIV. 3. 9 c. 666-667. Burası İskender'in MÖ 334 Şubat sonu Mart ayı başında Phaselis'ten Perge'ye doğru yola çıkarken izlediği sahil güzergahı olup denize paralel bir şekilde Pamphylia ovalarına doğru ilerlemekteydi. Ardından kendisi sahil yolu üzerinden Perge'ye doğru giderken ordusunun bir bölümüne de Pisidia üzerinden Perge'ye ilerlemelerini emretmişti.

Strabon'un (XIV. 3. 9 c. 666)'deki ifadesine göre, Phaselis çevresinde sahil boyunca geçitler bulunurdu ve bunların arasından iskender ordusunu geçirmişti... Burası daha çok havanın sakin olduğu zamanlarda yolcular tarafından kullanılan bir güzergahtı. Iskender kış mevsiminde buraya geldiği ve çoğu şeyi şansa bıraktığı için dalgalı denize rağmen ilerleyişini sürdürdü ve tüm gün boyunca askerlerine göbeklerine kadar suya batarak denizde yürüyüş yaptırdı (ayrıca krş. Plut. Aleks. XVII. 3-4). 
komplike bir yol ağıyla donatılı̆̆ı belgelenmiştir ${ }^{12}$. Söz konusu güzergahın Phellos (Kaş) ile Phaselis arasındaki bölümünde, Phellos, Kyaneai, Myra, Limyra, Gagai, Korykos üzerinden yolun sahili izlediği ifade edilmiştir ${ }^{13}$. Aynı güzergah Phaselis'ten sonra ikiye ayrılarak biri Mnara (Marmara) üzerinden ${ }^{14}$ diğeri ise sahili izleyerek Perge istikametine doğru ilerlemekteydi. Bu bakımdan söz konusu güzergah ya diğer bir alternatif yol ya da bağlantı niteliğindeki bir yan yoldu ${ }^{15}$.

Araştırmamız özelinde Phaselis'in Tekirova ve Çamyuva arasındaki yol sistemleri mercek altına alınmışı ır ${ }^{16}$. Amacımız merkezden başlayarak konsantrik daireler şeklinde Phaselis'in yakın çevresindeki yol ağını belirlemekti. Bu doğrultuda kentin gerek Hellenistik Dönem yerleşkesi olarak adlandırılan mevkiiden Olympos (Tahtalı) Dağı istikametindeki yol sistemleri gerekse Tekirova ve Çamyuva'ya doğru ilerleyen yollar, patikalar tespit edilmiştir. Bunlarla bağlantılı savunma sistemleri; kuleler, gözetleme ve tahkimatlı yerleşimler, polikhnikon (kentçik), kome'ler (köy) bulunup belgelendirilmeye çalışılmış ve topografik haritamıza eklemlendirilmiştir ${ }^{17}$.

Tarihi coğrafi açıdan kent bir tarafı deniz ve diğer yönlerinden karaya bağlantılı olduğu için araştırmamıza kent kapılarından başlanmış ve ilgili oryantasyonlardaki yol ve savunma sistemleri tespit edilmeye çalışımıştır. Bu bağlamda konuya sistematik bakış açısı getirmek amacıyla buluntular kendi içinde;

A) Phaselis - Tekirova Yol ve Savunma Sistemleri

B) Phaselis - Çamyuva Yol ve Savunma Sistemleri

C) Phaselis (Hellenistik Yerleşim ve Kapısı'ndan) - Olympos (Tahtalı) Dağı Yol ve Savunma

Sistemleri

başlıkları altında sınıflandırılmıştır.

\section{A) Phaselis - Tekirova Yol ve Savunma Sistemleri}

Phaselis kenti güney limanındaki Hadrianus Kapısı'ndan başlayan güzergah takip edilmiştir. Söz konusu kapı bir yandan kentin değişik dönemlerinde güney limanda konuşlandırılan mendirekler ve demirleme alanları ve iskelelerle ilişkilendirilse de aynı zamanda kentin güneye açılan yol güzergahından kente anıtsal girişi teşkil etmektedir. Bu monumental kapıdan kente giren yolun esas itibariyle kentin bir yandan Tekirova ile bağlantısını sağlarken diğer yandan Çöğmen tepenin

12 Sencer 2014, 123 vdd.

13 Bu güzergahın MÖ 334 yılının kış aylarında, İskender'in Pers Seferi sırasında, Phaselis'e gelirken izlediği yol olma olasılığı yüksektir. Diğer bir güzergah ise, Ksanthos üzerinden yola çıkan İskender'in, Neisa- Sinekçi Beli üzerinde Milyas'a (Elmalı Platosu'na) ulaşmış olmasıdır. İskender'in burada Phaselis'ten gelen elçilerle buluştuğu ve onların rehberliğinde Phaselis'e gittiği düşünüldüğünde Arykandos Vadisi'ni izleyerek Phaelis'e gitmiş olabilir. Diğer olasılıklar ise, kralın Kandyba'dan ve Kasaba Vadisi'nden ilerleyerek Arykanda'ya oradan da ya dağ yolunu kullanarak ya da Phoinike'ye kadar indikten sonra sahil yolunu kullanarak Phaselis'e ulaşmış olması şeklinde sıralanabilir. Konuya ilişkin olarak bk. Sencer 2014, 301 vd.; 404.

14 Şahin 2014, 302 vdd.

15 Salway 2007, 197 fig. 9; 200; Şahin 2014, 313; 317 vd.; 321; Onur 2016, 89 dn. 54.

16 Bunun nedeni Phaselis'in teritoryumunun bu kadar kısa süre içinde değerlendirilemeyecek ölçüde büyük olmasındandır. Epigrafik belgeler, antik kaynaklar ve tarihi coğrafi verilerden elde edilen veriler ışığında, Phaselis teritoryumunun fiziki ve beşeri sınırları karada; kuzeyde Gökdere Vadisi'ne, güneyde Üç Adalar'dan Tahtalı Dağı İstikametinde çekilecek bir hat doğrultusunda ilerlemekte, batıda ise Çandır Vadisi'ni kaplamaktadır; denizde ise kabaca Üç Adalar ile Sıçan Adası arasında uzanmaktadır.

17 Phaselis'in hinterlandında antik kaynaklar ve epigrafik belgeler aracılığıyla bildiğimiz irili ufaklı 15 kentçik ile köyler, çiftlik yerleşimleri, kasabalar ve alan/yerleşim arkeolojisine yönelik şu ana kadar kapsamlı bir çalışma yürütülmemiştir. 
etrafından otel yapılmak istenen alana doğru ilerleyen bir güzergahla bağlantılı olduğu saptanmıştır.

Bunlardan Tekirova istikametine doğru ilerleyen yolun Phaselis'in hemen güneyindeki Bostanlı Koyu istikametine doğru ilerleyip Çöğmen Tepe'nin önünde ikiye ayrıldığı düşünülmektedir. Fakat söz konusu güzergahın ikiye ayrıldığı yol kavşağı aramalara karşın bulunamamıştır. Bu durum gerek Phaselis'in güney sahilindeki kumul hareketine, gerek 1980'li yıllarda bu lokasyondan başlayarak kentin tel örgü ile çevrelenmesi çalışmalarında yürütülen inşaat faaliyetlerine gerekse doğal nedenlere (dalga hareketleri, rüzgar, bitki örtüsü ya da üzerinin toprakla kaplanmış olması etc.) bağlanabilir. Ancak yolun gerek Çöğmen Tepe üzerinden Bostanlı Koyu'ndaki İnciryalısı mevkiine doğru ilerleyen bölümü gerekse tepenin eteklerinden başlayıp lagünün kenarı boyunca iç bölgelere giden bölümü yer yer tespit edilmiştir. Söz konusu yol bir yandan Çöğmen Tepe'nin etrafını dönerken bir taraftan da tepe eteklerinden başlayarak Antalya-Kumluca istikametine doğru ilerlemektedir. Bu doğrultuda tahkimli çiftlik yerleşimleri ile değişik ölçülerde evler, işlikler ve yapılaşma faaliyetleri tespit edilmiştir. Güzergahların daha iyi anlaşılabilmesi için bu bakımdan bu bölümün iki alt başlık altında incelenmesi daha uygun olacaktır.

\section{A1) Phaselis - Tekirova arası Yol ve Savunma Sistemi}

Bu güzergah Phaselis'in güney limanından başlayarak Çöğmen Tepe'nin eteklerinden itibaren yer yer ana kaya düzeltilmek suretiyle inşa edilmiştir. Yolun bir bölümü ise Çöğmen Tepe'nin hemen deniz tarafında bir taraftan yer yer 2.5 m’yi aşan kuru duvar tekniğiyle, polygonal kromit taşlarla örülmüş bir istinat duvarıyla desteklenmiştir. Söz konusu güzergahın, antik kaynaklarda Büyük İskender'in Pers seferi sırasında bir grup Phaselisli tarafından MÖ 333 yııının ilk aylarında Phaselis'e davet edilmesi üzerine kullandığı güzergah olduğu düşünülmektedir. Zira İskender Phaselis'teki ziyaretini tamamladıktan sonra ${ }^{18}$ ordusunun bir kısmıyla gene deniz yolunu izleyerek Perge'ye doğru yola çıkmıştır.

Bu güzergah Çöğmen Tepe'nin hemen deniz tarafından ilerleyerek Inciryalısı Mevkii'ne doğru devam etmektedir. Bu alanda yapılan tetkikler sonucunda sahile yakın bir konumda geç antikçağa (bölgenin MS V.-VI. yüzyıl kilise mimarisine

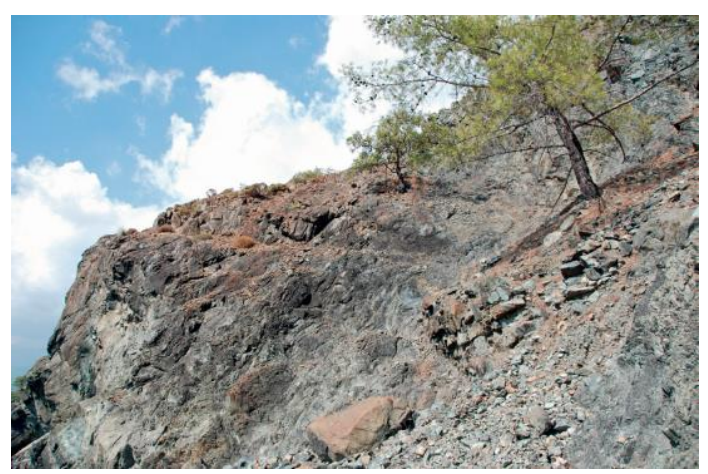

Phaselis Sahilindeki Çöğmen Tepe'nin Üzerinde Yer Yer Anakayanın Düzeltilmesiyle Yer Yer Istinat Duvarlarıyla Tahkim Edilmiş Yol Güzergahı (istinat Duvarları Çam Ağacının Altında) benzer) tarihlenen bir kilise tespit edilmiştir. Söz konusu kilise üzerinde uzmanlar tarafından fotoğraflama, plan, çizim, belgeleme ve yayım çalışmaları gerçekleştirilmiştir ${ }^{19}$.

Bostanlı sahilinden güneye Tekirova istikametine doğru araştırmalar sürdürülmüş olup alanda herhangi bir yol kalıntısı saptanamamıştır. Ardından Bostanlı sahiliyle Tekirova'yı birbirinden ayıran Alatepe üzerinde tetkikler gerçekleştirilmiştir.

18 Bir aya yakın olmak kaydıyla, tam olarak kaç hafta kaldığı bilinmemektedir.

19 Mergen 2015, 286 vd. 


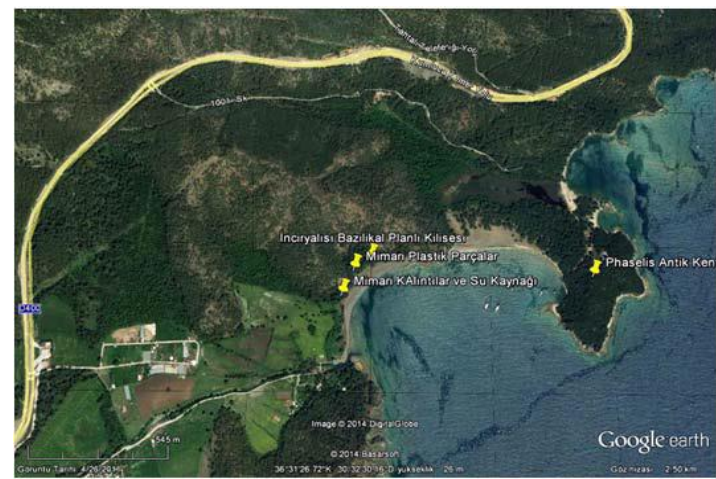

Bostanlı Kumsalı, İnciryalısı Bazikilası Lokasyonu

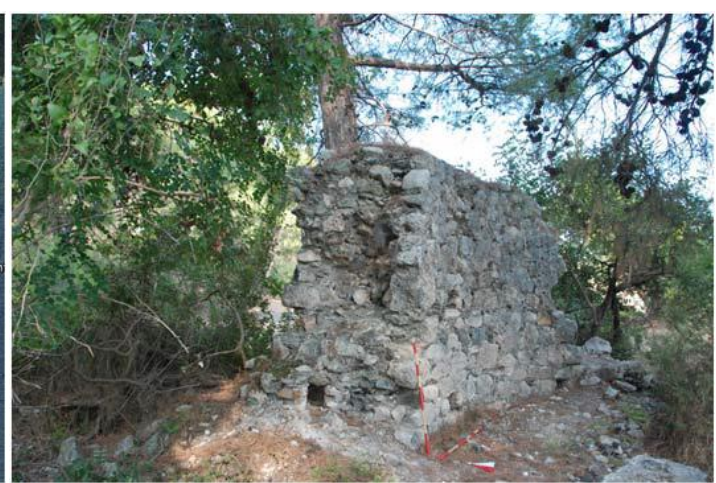

Inciryalısı Bazilikası

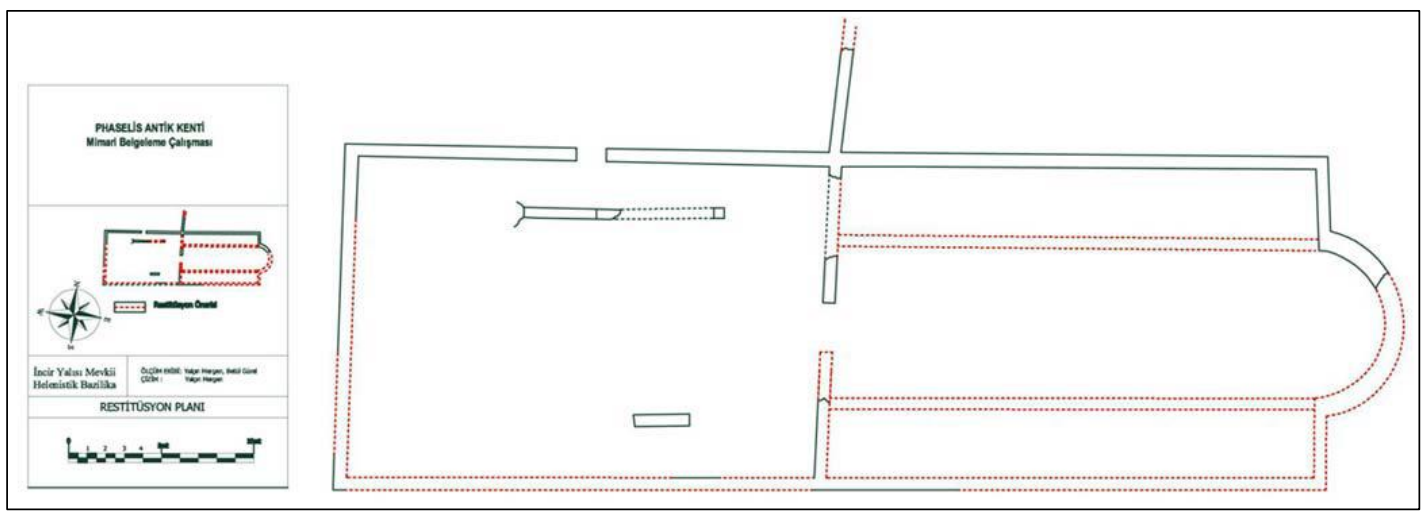

İnciryalısı Bazilikası Restitüsyon Planı, Yalçın Mergen 2015

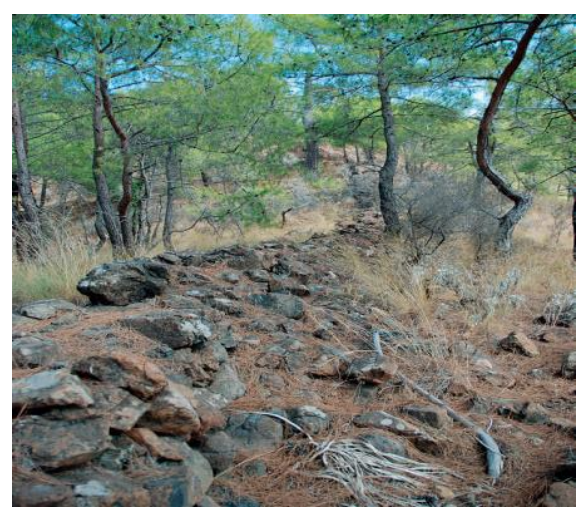

Phaselis- Alatepe Tahkimatı

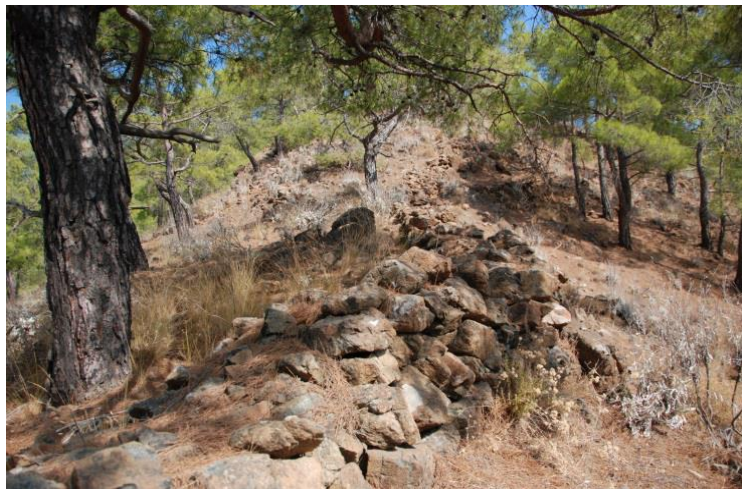

Phaselis- Alatepe Tahkimatı

Alatepe'nin sahil bölümü ve tepe üzerinde herhangi bir arkeolojik kalıntıya rastlanılmamıştır. Ancak tepenin eteklerinden Tekirova yönüne doğru uzanan boğazda neredeyse tepenin en sarp yerlerine kadar uzanan bir tahkimat tespit edilmiştir.

Daha önceki çalışmalarımızda tespit edilen ancak gerektiği ölçüde belgeleyemediğimiz bu tahkimat duvarının tepenin sırtı boyunca yak. $800 \mathrm{~m}$ boyunca yaklaşık $1 \mathrm{~m}$ yükseklik ve 80 ile $105 \mathrm{~cm}$ arasında değişen genişlikte doğu-batı istikametinde uzandığı görülmektedir. Detaylı yapılan incelemeler sonucunda surun yer yer ufak çaplı kulelerle tahkim edildiği ve topografyaya uygun olarak tepeler arasında iki farkı yerde kapılar vasıtasıyla Tekirova ve Phaselis yönüne kontrollü geçiş imkanı sağladığı saptanmıştır.

Doğu-batı istikametindeki tepeleri izleyerek devam eden surun kuzey güney istikametindeki 
diğer bir tepeyle de bağlantılı olduğu ve $T$ şeklinde bir plan sergilediği görülmüştür. Surun bitimindeki boğazda ise geçişi kontrollü kılan ve yeri geldiğinde kapatan bir duvar bulunduğu belgelenmiştir. Doğu-batı istikametinde olup yak. $60 \mathrm{~cm}$ genişliğe ve $9 \mathrm{~m}$ uzunluğa sahip olan söz konusu duvar, bir yönüyle Tekirova istikametindeki lagün ile diğer tarafında Bostanlı kumsalında Sundance Oteli istikametindeki güzergahı kontrol altında tutuyor olsa gerektir.

Duvarın hemen arkasında, yerel kromit şekilsiz kayalardan kuru duvar örgüsüyle inşa edilmiş olup izlenebildiği kadarıyla dikdörtgen plana sahip bir yapı kalıntısı tespit edilmiştir. Yapının söz konusu geçişi denetleyen kontrol ünitesi olabileceği görüşü üzerinde durulmuştur. Bu durum sur duvarının geç antikçağda Phaselis ile Olympos arasındaki yolun korunması ve olası durumlarda savunulması amacıyla inşa edilmiş olabileceğini düşündürmektedir.

Duvar ile kontrol ünitesinin yer aldığı geçidin hemen doğusundaki tepenin üzerinde gözetleme amaçlı kullanılmış olması muhtemel tahkimli bir oda tespit edilmiştir. Kuru duvar tekniğiyle yerel şekilsiz kromit taş parçalarından ve kireçtaşından inşa edilmiş yapının zaman, doğa ve insan tahribatı sonucu planını saptamak mümkün gözükmemektedir. Alanda ayrıca eskiden açılmış $2 \mathrm{~m}$ çapında kaçak kazı çukuru bulunmuştur. Yapının iç kısmında geç antikçağa tarihleyebileceğimiz ilginç ağız yapısına sahip devetüyü renginde seramik bir kaba ait parçalar bulunmuştur. Yapının hassas koordinatları alınmış ve belgelenerek topografik haritamıza işlenmiştir ${ }^{20}$.

Bunu yaparken sur sisteminin etrafındaki yerleşim arkeolojisine ilişkin mimari ve materyal kültür kalıntıları da belgelenmeye çalışımıştır. Öncelikle sur ile Tekirova'ya doğru açılan lagünün
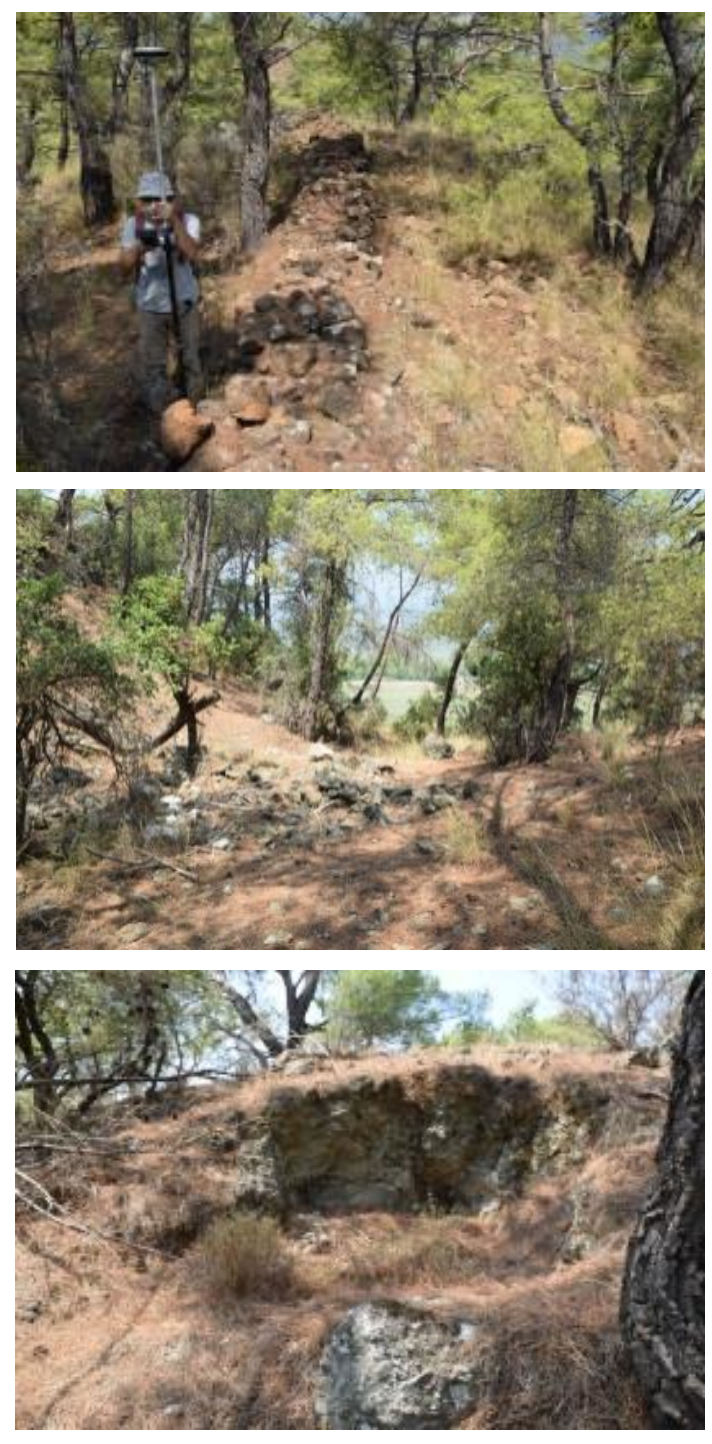
arasında (şimdiki lagündeki su yükseltisinin hemen önünde) planını belirleyemediğimiz kesme taş bloklardan inşa edilmiş çiftlik/yapıya ait kalıntılar saptanmıştır. Yapıya ait blok ve kalıntıların hemen etrafında çatıya ait kiremit parçaları ve günlük kullanıma ait orta düzeyde lokal seramik parçaları gözlemlenmiştir. Ancak yer yer balçık zeminin içinde kalmış blokların yoğun bitki örtüsünün yanı sıra zaman ve insan tahribatına uğramış olmasından ötürü planının saptanması mümkün olmamıştır. Bu bakımdan konutun sadece koordinatları alınmış ve topografik haritamıza işlenmiştir.

20 Önceki sezonlarda belgelediğimiz bu savunma duvarının hassas ve sapma oranını minimuma indirgeyen corse gps aletiyle güzergahı takip edilmiş ve koordinatları alınarak topografik haritamıza eklenmiştir. 
Yapıyla sur arasındaki bölümde teraslama duvarı ile yolu destekleyen istinat duvarı olma işlevi taşıması muhtemel bir güzergah olduğunu düşündüren bir sıra şekilsiz kromit kaya parçalarından inşa edilmiş duvar kalıntıları da gözlemlenmiştir.

Ardından surun yaklaşık $150 \mathrm{~m}$ batısındaki tepenin kuzey eteğinde 3 odalı bir çiftlik evi tespit edilmiştir. Yapının planı büyük ölçüde okunabilir vaziyettedir. Kuzey güney doğrultulu bu yapının hemen önünde tarım amaçlı doğu batı doğrultulu birbirinden $5 \mathrm{~m}$ arayla iki teras duvarı

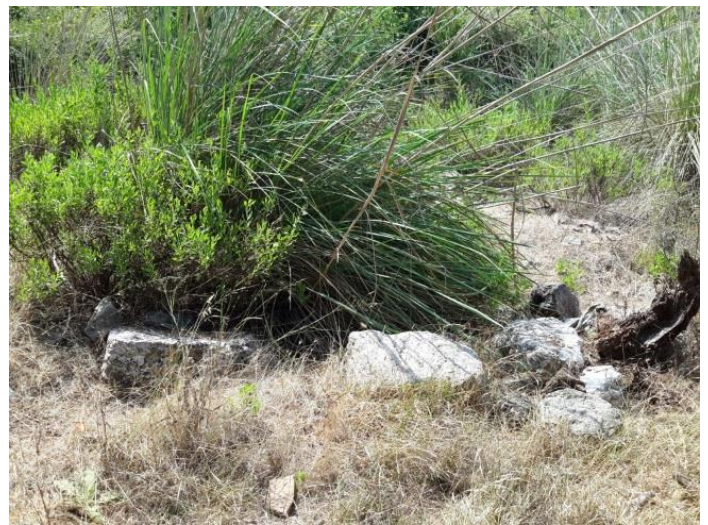

Tanımsız Çiftlik tespit edilmiştir. Konut antikçağda göl olması gereken bereketli bir polyenin hemen karşısındaki tepeciğin eteğinde yer almaktadır. Kuru duvar tekniğiyle inşa edilmiş yapı yak. $70 \mathrm{~cm}$ kalınlığındaki bloklarla çevrilmiştir ve duvarların yüksekliği yer yer 150 cm'yi aşmaktadır. Özellikle kuzey duvarı oldukça düzgün işlenmiş kesme taş bloklarından $(60 \times 50 \mathrm{~cm})$ inşa edilmiştir.

Söz konusu çiftlik evinin hemen üstündeki tepecik üzerinde yapılan incelemede tek odalı dikdörtgen bir yapı kalıntısı tespit edilmiştir. Yapı yak. 6.30 x $5.10 \mathrm{~cm}$ ölçülerinde dikdörtgene yakın plana sahiptir. Küçük ve orta boy lokal şekilsiz kromit kaya parçaları ile kireç taşından sıva kullanılarak inşa edilmiştir. Geç antikçağa tarihlenen bu yapı daha sonradan tamirat görmüş ve kuru duvar tekniğiyle temelin yak. $70 \mathrm{~cm}$ üzerinden yeniden yükseltilmiştir. Bu şekilde yer yer $170 \mathrm{~cm}$ duvar yüksekliğine sahip olmuştur. Yapı coğrafi konumu itibariyle bir yandan Tekirova ve 3 adaları görürken diğer taraftan Phaselis istikametini gözleyebilir durumdadır. Plan üzerinde oynandığında pencere ve kapı yönlerini bulmak mümkün değildir. Yapı etrafında az da olsa geç antikçağa tarihlenebilecek çatı

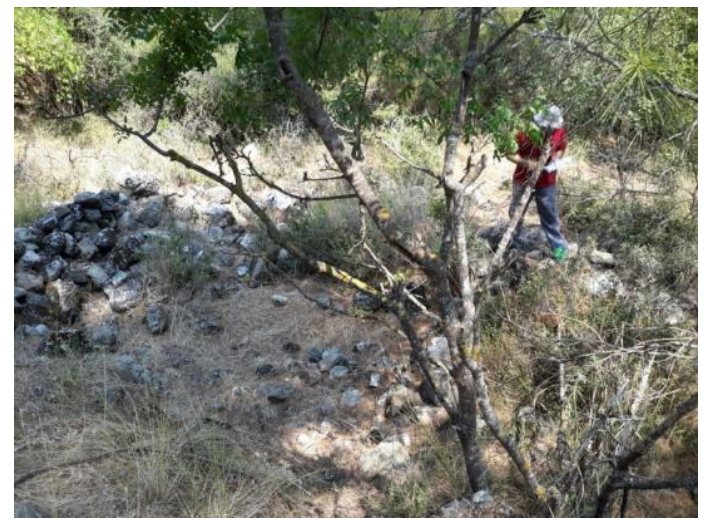

Nişli Çiftlik kiremit ve seramik parçaları mevcuttur.
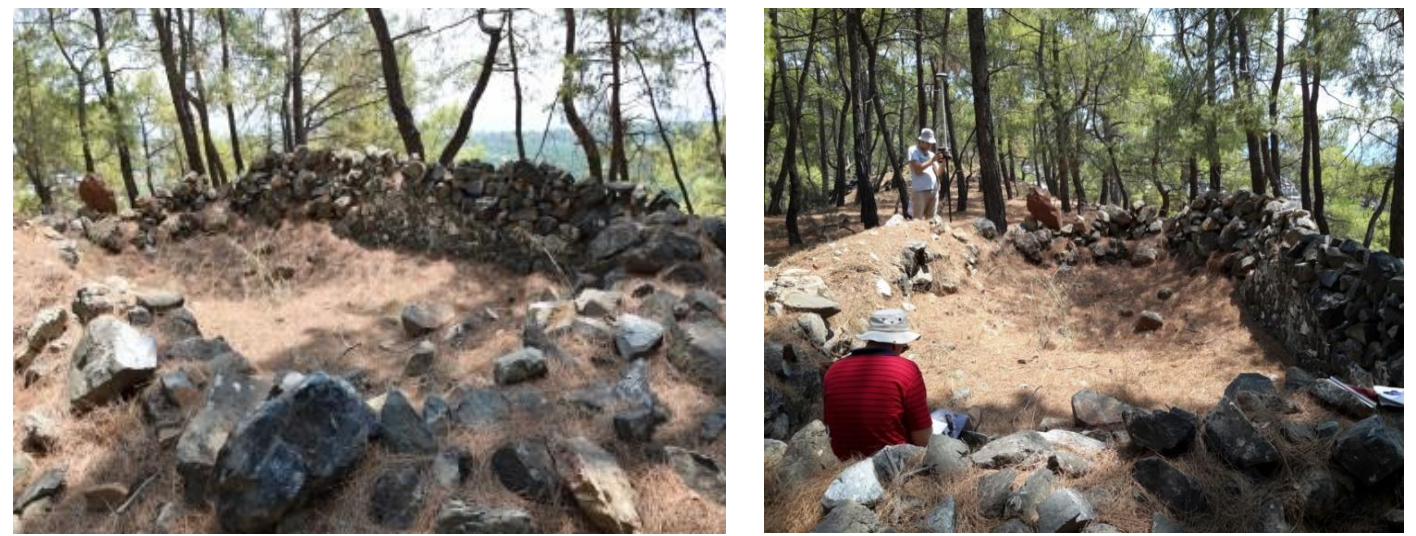

Gözetleme Kulesi 


\section{A2) Phaselis-Çöğmen Tepe Çevresi Yol sistemi}

Kentin güney limanı ile Bostanlı Plajı arasında yükselen Çöğmen Tepe'nin, kuzey ve kuzeybatı yamaçları boyunca, Phaselis'in batı nekropolis'inin uzanım alanında devam eden bir yol saptanmıştır. Söz konusu yol yer yer doğal ve kenti çevreleyen çitlerin yapımı sırasında tahrip olsa da tepenin yamaçları boyunca ilerleyerek modern Antalya Kumluca istikametine doğru uzanmaktadır.

Rixos'a tahsis edilmiş arazinin [878 parsel] içinden geçmekte olan bu yolun kentin ulaşım ağının bir parçası olduğu ve anı zamanda Phaselis-Olympos güzergahlarından birinin de bu doğrultuda ilerlemiş olabileceği düşünülmektedir. Zira bu alanda tespit edilen yaklaşık $33 \times 40 \mathrm{~m}$ ölçülerindeki yapının, Tabula Peitungeriana'da ${ }^{21}$ Phaselis-Olympos arasındaki yol güzargahı üzerinde işaretlenen çift kuleli konaklama istasyonu olması intimali bulunmaktadır. Bu alanda söz konusu muhtemel statio ${ }^{22}$ (han kalıntısı) ile işlikleri olan yapı kalıntıları ve çevre duvarlarıyla tahkim edilmiş çiftlik yerleşimleri gibi önemli materyal kültür bulguları tekrar tetkik edilmiştir ${ }^{23}$.

Görülebilen mimari unsurlar doğrultusunda konumlandırılan söz konusu yapı topluluğunun, çevresinde ve yüzeyde izlenebilen mimari yapı elemanları dolayısıyla daha geniş bir alana yayıldığı düşünülmektedir. Ardından söz konusu alan üzerindeki antik güzergahlar tekrar incelenmiş, koordinatları alınmış, orientasyonları incelenmiş ve bu alanın Phaselis'e ait bir dış mahalle olduğu saptanmıştır. Dış mahalleye gelen ve oradan gene Çöğmen Tepe'nin güneybatısından

21 Tabula Peutingeriana=Peutinger Haritası adlı eser MS ca. 1265'te Kormalı bir keşişin on iki parşömen üzerinde çizdiği eski - muhtemelen MS IV. yüzyılın Roma güzergahlarını ve yol üzerindeki kalıntılarını gösteren- bir haritanın kopyasıdır.

22 Herodotos'un (V. 52-54) anlatısına göre, Persler MÖ V. yüzyılda Sardeis ile Susa arasında 'Kral Yolu' olarak adlandırılan 13500 stadia boyunca uzanan güzergah üzerinde belirli aralıklarla toplam 111 tane yapı inşa

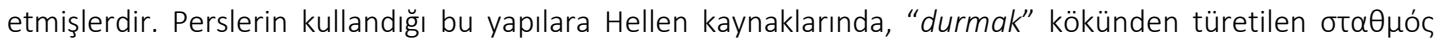
(stathmos) ismi verilmiştir. Roma dünyasında görülen bu tür yapılar da esas itibariyle Perslerin kullandığı kral yolu ve posta sisteminden esinlenmiş gözükmektedir. MS IV. yüzyıldan itibaren yol boyu inşa edilen bu tür yapılar için mansio ve mutatio terimleri kullanılmaya başlamıştır. Mansio terimi "durmak" anlamına gelen Latince manere fiilinden türetilmiştir. Roma dünyasında yol boyu belirli aralıklarla mansio'ların inşa edilmesi eyaletler ile Roma arasındaki iletişimin güvenli ve hızlı bir şekilde sağlanması amacıyla Augustus'un MÖ 20 yılında yaptığı düzenlemeye kadar geri gider. Bir günlük yol mesafesinde inşa edilen mansio'ların arası genellikle $40 \mathrm{~km}$ kadardır. Mansio'lar farklı yapı birimlerinden oluşur. İstasyonda görevli askerlerin kaldığı gözetleme ve koruma amaçı tesislerin (milites stationarii) yanında üst düzey memurlar için misafirhane (praetoria), hamam (balnea) ve devlet posta ulaşımı için tesis edilmiş bir servis (angaria) bulunurdu.

Antikitede Roma yolları boyunca gerek üst düzey devlet memurlarının ağırlandığı misafirhaneler; gerekse yoldan geçen tacir veya yolcuların kullandıkları han ve kervansaray işlevi gören kısa süreli konaklama yapıları zaman içinde değişen farklı plan ve adlandırmalarla anılmışlardır. İmparator Nero'nun MS 61 yılında inşa ettirdiği via militaris 'askeri yol' üzerinde taberna ve praetorium olarak isimlendirilen ve konaklama amaçlı yapılar konuşlandırılmıştır. Taberna'nın küçük barınak; praetorium'un ise, üst düzey idarecilerin ikamet ettiği konforlu yapılar olduğu varsayılmaktadır. Gene Trakya'da imparator Marcus Aurelius (MS 161-180) stabulum olarak isimlendirilen, hayvanların kalacağı ahırlarla arabaların park edileceği mekanlara sahip konuk evlerini tamir ettirmiştir. Ayrıca Suetonius (Vit. VII. 7. 3 'Vitellus'), Vitellius'un Roma'ya giderken yol üzerindeki stabula ve deversoria'da konaklayan katırcılara (muliones) ve yolculara (viatores) sabahları kahvaltı yapıp yapmadıklarını sorarak ve sıra dışı dostluk göstererek halkın kendisine sevgi beslemesini sağlamaya çalıştığını aktarır. Bu anlatımdan stabula'da daha çok arabacı ve katırcıların; deversoria'da ise yolcuların kaldığı anlaşılmaktadır. Konuya ilişkin olarak ayrıca bk. Takmer - Tüner Önen 2007, 9 vd.

23 Söz konusu arkeolojik malzemeler fotoğraflanarak, hassas gps koordinatları alınmış, rölöve ve restitüsyon çizimleri ile yapının planı çıkartıldıktan sonra topografik harita üzerinde konumlandırılmıştır. 
Bostanlı Koyu’na doğru ilerleyen yol güzergahının bazı bölümleri modern şose yol tarafından tahrip edilmiş olmakla birlikte büyük ölçüde takip edilmiştir. Bunun akabinde Rixos'a ait birinci derece sit alanı içindeki mansio ve 3 tane tanımlanamayan yapı kalıntısıyla parselin hemen dışındaki yapı kompleksleri ile işlik kalıntısı ve yörük mezarlığındaki kabir taşlarının koordinatları alınarak topografik haritamıza işlenme çalışmaları tamamlanmıştır.

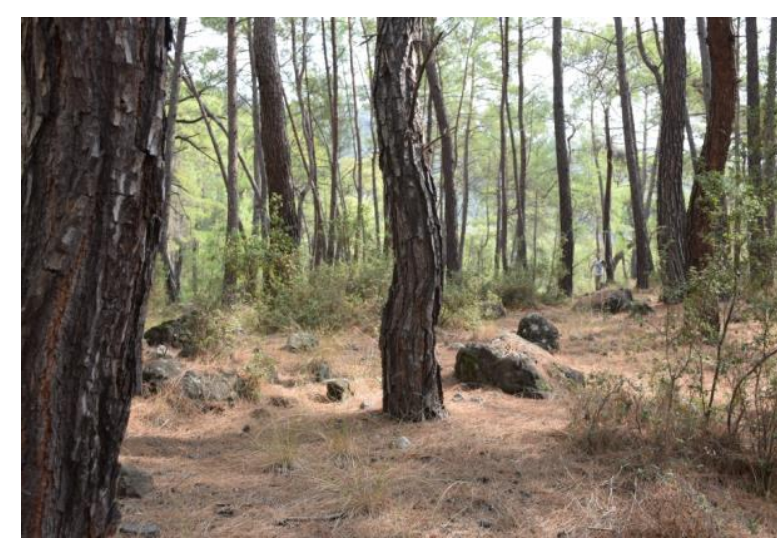

Phaselis-Mansio Arası Çöğmen Tepe Etrafından ilerleyen Yol

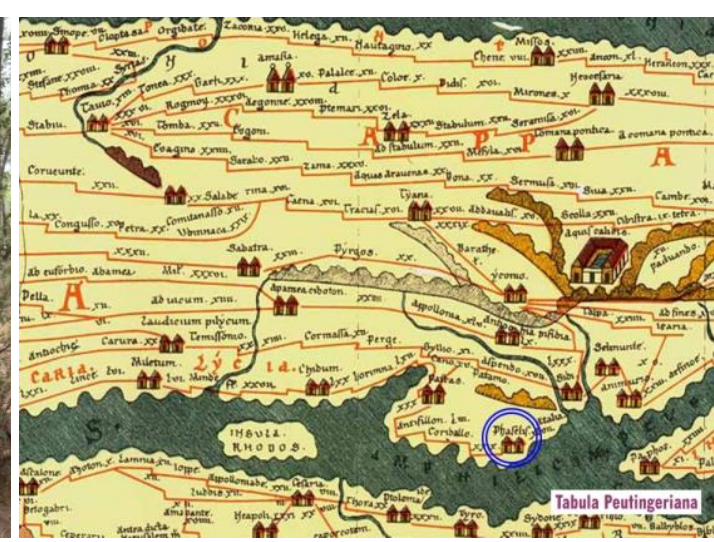

K. Miller, Itineraria Romana römische Reisewege an der Hand der Tabula Peutingeriana, Stuttgart 1916, segment IX

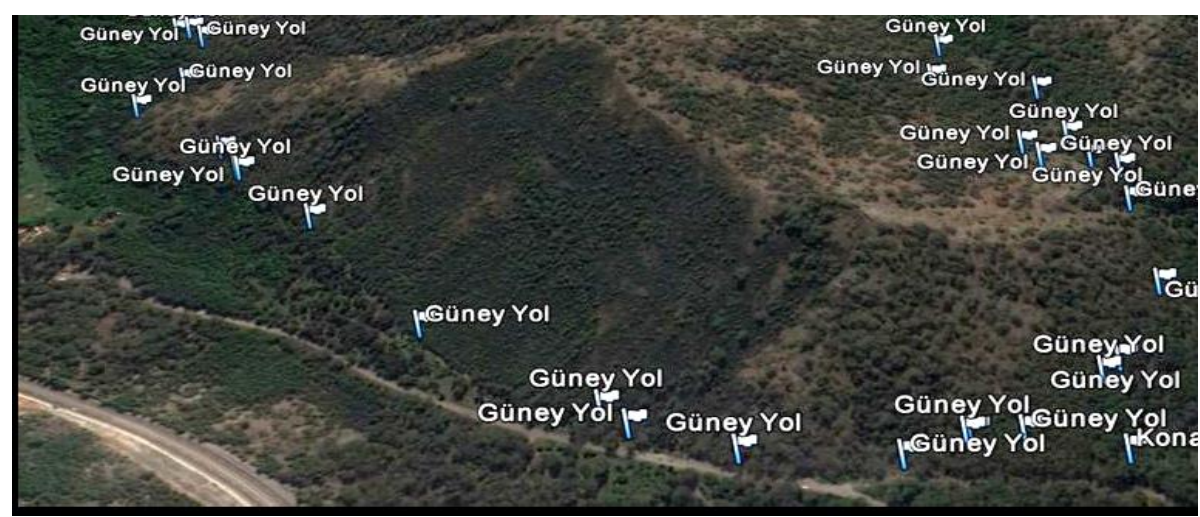

Güney Yolu

Söz konusu mansio yapısının güney-güneybatısında bulunan -olası kuleli?- çiftlik ${ }^{24}$ ve işlik yapı

24 Kule çiftlik olarak tanımlanan yapı topluluğu, Phaselis Antik Kenti'nin güneybatısında kente karayolu ile yaklaşık $3 \mathrm{~km}$ mesafede, D400 karayolunun hemen kenarında yer alan $11 \mathrm{~m}$ rakımlı bir tepe üzerindeki düzlüğün doğusunda ve yaklaşık 36³1'24.12"K, 30³1'40.02"D koordinatlarında yer almaktadır. Yapı topluluğunun kule çiftlik olarak tanımlanmasının en önemli nedeni konumu, kullanılan malzemenin kalitesi ve kalın duvar ölçüleri açısından Lykia ve Kilikya'da örnekleri yer alan kule çiftliklerle benzerlikler göstermesidir. Ayrıca yapıya ait ve geniş bir alana yayılan duvarların oldukça kalın bir yıkıntı katmanı altında kalmış olması yüksek cepheli bir yapı olduğu kanısını uyandırmaktadır. Yukarıda tarifi verilen tepenin doğu yamacı boyunca uzanan suni bir teras üzerine konumlanan yapı topluluğunun hem teras hem de kapalı mekân duvarlarına ait kalıntılar yüzeyde rahatılıla görülebilmektedir (Yalçın Mergen'in konuyla ilgili raporundan yararlanılmıştır). Tepenin üzerinde kuzeydoğu - güneybatı doğrultusunda uzanan kapalı alanlarla ve avluya ait birimler 33.73 × 10.88 m ölçülerine sahip bir alanda izlenebilmektedir. Kapalı alanların bitişi ile yapının yerleştiği teras 15 m’ye kadar genişleyerek kuzeydoğu yönünde ve yamaç boyunca teras duvarları yak. 55 m devam etmektedir. Söz konusu terasın güneybatısında bulunan ve duvarlarla sınırlanmış olasılıkla bir avlu içinde yer alan ana çiftlik binası 0.80 m ölçüsüne sahip duvarlarla inşa edilmiştir. Düzgün kare planlı ana yapının duvarlarının kalınlığı ve benzer örnekleri nedeniyle iki ya da üç katlı olması olasılık 
topluluklarına ${ }^{25}$ ait kalıntılar da yeniden tetkik edildikten sonra restitüsyon planları hazırlanmıştır. Kullanılan malzemenin kalitesi ve kalın duvar ölçüleri, bina kompleksinin oldukça geniş bir alana yayıldığını göstermektedir. Ayrıca duvarların bir kısmının oldukça kalın bir yıkıntı katmanı altında kalmış olması, çiftlik olarak tanımlanan yapının yüksek cepheli olduğunu varsaymamıza olanak tanımaktadır. Yapay bir teras üzerine konumlanan yapı kompleksinin teras ve kapalı mekân duvarlarına ait kalıntıları yüzeyde rahatıkla izlenebilmektedir. Yapı kuzeydoğugüneybatı doğrultusunda 33,73×10,88 m ölçülerindedir. Kalıntılarının güneybatısında duvar kalınlığı 0,80 m genişliğine sahiptir. Kuru duvar tekniğiyle inşa edilmiş düzgün kare planlı ana yapının duvarlarının kalınlığı ve benzer örnekleri nedeniyle iki ya da üç katlı olduğu düşünülebilir.

Kule çiftlik yapı topluluğunun yaklaşık 175 m kuzeyinde ve çiftliğin yer aldığı tepenin hemen altında yer alan işlik 14×12,65 m ölçülerindedir.

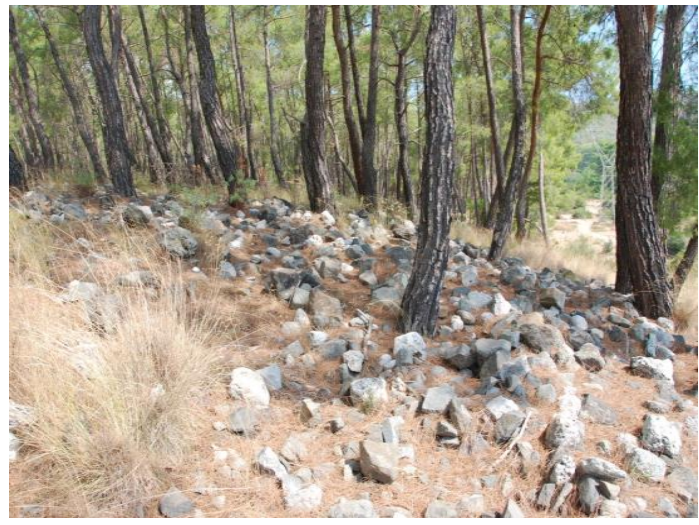

Kuleli Çiftlik

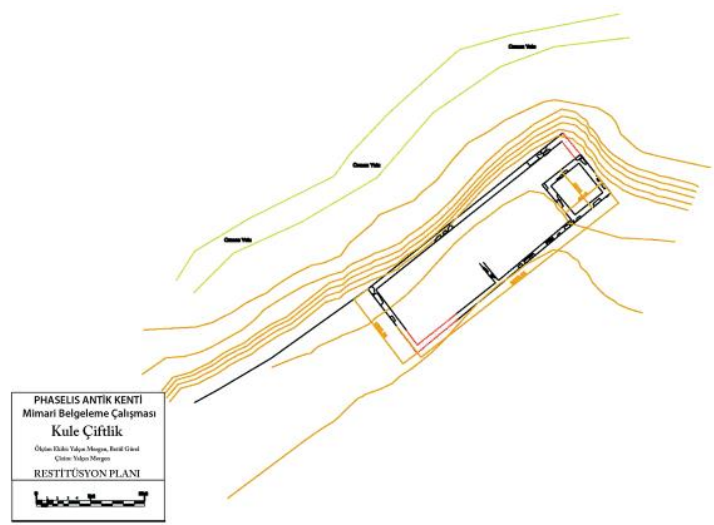

Kuleli Çiftlik Restitüsyon Planı (Y. Mergen)

dâhilindedir. Yapıda kullanılan malzeme ve teknik özellikler Phaselis'te yaygın bir biçimde görülen sandık (sandviç) duvar tekniği ile uyumludur. Kullanılan malzeme duvarın dış yüzlerinde büyük boyutlu ve kalın plakalar halinde yontulmuş kesme-taş, ara malzeme ise moloz-taştır. Yapı topluluğunun inşa edildiği tepenin güneydoğu yamacında yer alıyor olması tesadüfî değildir zira çiftlik binasının bulunduğu kısım tarım arazisi olarak kullanılmaya müsait olan düzlüklere yöneliktir. Bu nedenle tepenin ve çiftlik binasının güneydoğusunda uzanan düzlükler bu çiftliğin mülkiyet sınırları dâhilinde olmalıdır (Yalçın Mergen'in ilgili raporundan yararlanılmıştır).

25 Phaselis teritoryumunda yapılan çalışmalar, kentin çevresinde oldukça geniş, zengin ve yaygın imar faaliyetleri olduğunu, Phaselis'in tipik bir antik dönem kent örgütlenmesine sahip olduğunu göstermektedir. Çalışmalar sırasında belgelenen "mansio", "çiftlik" ve "işlik" olarak tanımlanan yapıların birbirine ve kente olan yakın mesafeleri kentin ekonomik örgütlenmesi ve sosyal yapısı hakkında çok önemli ipuçları sunmaktadır. Lykia Bölgesi kent organizasyonları için de önemli açılımlar getireceği anlaşılan bu bulguların birlikte ve tahrip olmadan mutlak değerlendirilmesi gerekmektedir. Kent çevresinde iki sezonluk kısa bir çalışmayla dahi elde edilen veriler Phaselis yakın çevresinin yoğun olarak ve farklı işlevlere cevap vermek amacıyla iskân edildiğini göstermektedir. Lykia Bölgesi'nin diğer kentlerinde yapılan çalışmalarda, kentsel ekonomik ve sosyal organizasyon için bu derece verili sonuçların henüz elde edilmemiş olması Phaselis kentini Lykia Bölgesi arkeolojisi, kültür ve uygarlık tarihi açısından öne çıkarmakta ve korunması gerekli önemli bir "ulusal kültür mirası" olarak işaret etmektedir. Yukarıda sayılan unsurlar, "kule çiftlik" ve işlik olarak değerlendirdiğimiz yapılar için de geçerlidir. İki yapı topluluğunun mekânsal olarak birbiri ile yakınlığı, inşa malzeme ve tekniği açısından aynılığı her iki yapı topluluğunu birlikte değerlendirmeyi zorunlu kılmaktadır. Birbiri ile bağlantılı bu iki yapı topluluğunun tamamlayıcı bazı unsurlarının (örneğin: Mülk sahibi ve ailesine ait nekropolis alanı, çiftliğe ait granarium, çiftlik ve işliğe ait köylülere ait yerleşimin) bu alanda ve yapılara yakın konumda bulunması yüksek olasılığa sahiptir (Söz konusu yapı ekibimiz üyesi Y. Mergen tarafından çalışılmıştır). 


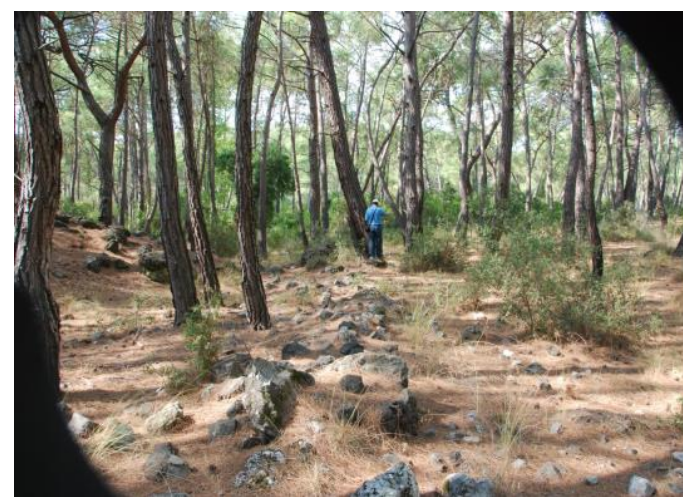

Kuleli Çiftlik Tahkimat Duvarları

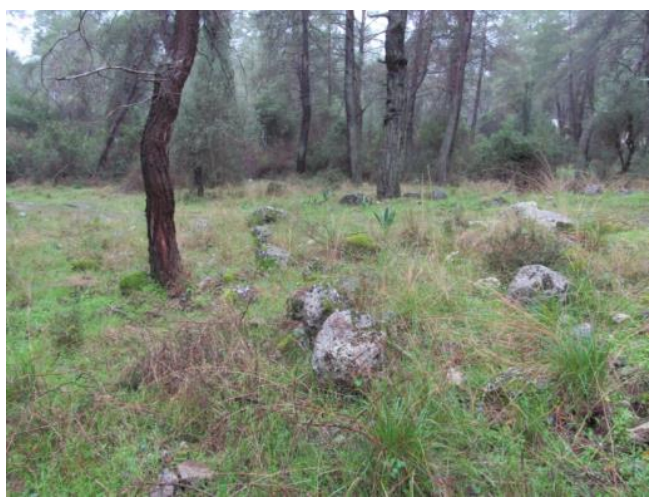

Çiftlik

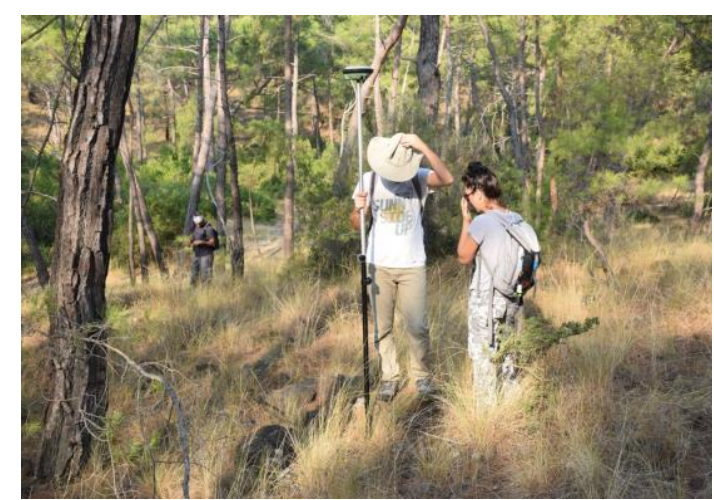

Kuleli Çiftlik Tahkimat Duvarı Temel Kalıntıları

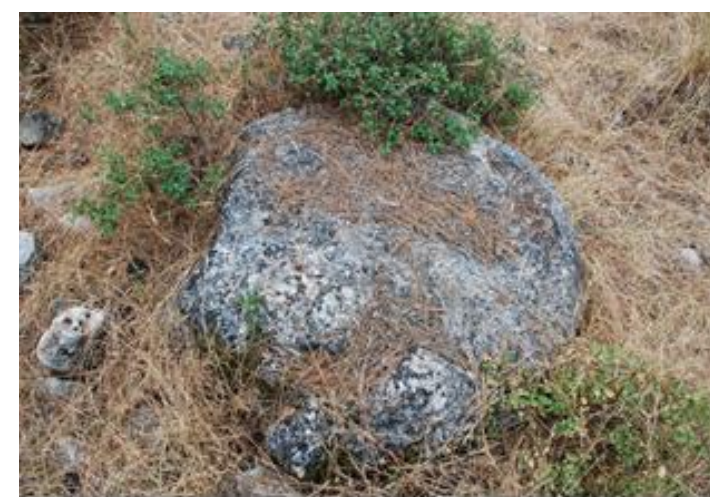

İ̧̧lik

Alandan geçen orman yolu dolayısıyla oldukça tahrip edilmiş olan yapının çevresinde çok sayıda büyük boyutlu saklama kaplarına ait pişmiş toprak malzeme parçaları ve preslere ait taş malzemeler görülmektedir. Çiftlik ve işlik ${ }^{26}$ yapılarının doğu-güneydoğusunda uzanan düzlük alan

26 İşlik olarak tanımlanan yapı grubu kule çiftlik yapı topluluğunun yaklaşık 175 m kuzeyinde ve çiftliğin yer aldığı tepenin hemen altında yer almaktadır. Günümüzde orman içi ulaşımını sağlayabilmek amacıyla açımış olan orman yolunun üzerinde yer alan mekanları sınırlayan duvarların izleri görülmektedir. Söz konusu yolun açılması sırasında büyük oranda tahrip edildiği anlaşılan mekânlara ait molozlar yolun iki yanında görülmektedir. Günümüze sağlam olarak ulaşan duvarlar 14 × 12.65 mlik bir alana yayılmaktadır. Duvarların sınırladığı mekanlar ve çevresinde yüzeyde görülebilen çok sayıdaki büyük boyutlu saklama kaplarına ait pişmiş toprak malzeme parçaları ve işlevsel olduğu üzerlerindeki yiv, hazne gibi unsurlardan dolayı anlaşılabilen büyük boyutlu -olasılıkla preslere ait- taş malzemelere dayalı olarak bu mekanların bir işliğe bağlı olabileceği anlaşılmaktadır.

Günümüze görülür biçimde ulaşan bu üç mekânın çevresinde, özellikle de yakında bulunan bir dere yatağının mansap ve memba yönlerinde çok sayıda yapı malzemesi niteliğine sahip kesme-taş yığınları ve dere yatağının güney ve kuzey kıyılarında pişmiş toprak malzeme görülebilmektedir. Bu durum işlik yapı topluluğunun oldukça geniş bir alana özellikle de güney ve güneybatıya doğru yayılım gösterdiğini kanıtlamaktadır.

Yapıda kullanılan inşa malzemesi hem çiftlik yapısı ile hem de Phaselis Antik Kenti'nin erken tarihli yapı malzemeleri ile uyumlu gözükmektedir. Oldukça büyük boyutlu kesme ve kaba-yonu kesme-taş malzemenin sandık duvarları inşa etmekte kullanıldığı anlaşımaktadır.

Mimari ve pişmiş toprak malzemenin dışında, ilgi çekici bir başka bulgu ise söz konusu üç mekânın kuzeyinde ve yüzeyde görülebilen "islam dönemi" mezarlarıdır. Kuzey - güney doğrultulu dört adet mezar tespit edilmiştir. Mezarların malzeme ve tekniğine bakarak 20. yüzyılın ilk çeyreğine veya 20. yüzyı öncesine ait oldukları söylenebilir.

Söz konusu işliğin çiftliğe olan yakın mesafesi bu iki yapı topluluğunu birlikte düşünmeyi zorunlu kılmaktadır 
antikitede tarım amaçlı kullanılmış olmalıdır. Ayrıca yapı topluluğunun yakın çevresinde yapılan çalışmalarda bu alanda başka mimari kalıntılar ve modern çağlara kadar kullanılmış eski bir yörük mezarlığı tespit edilmiştir.

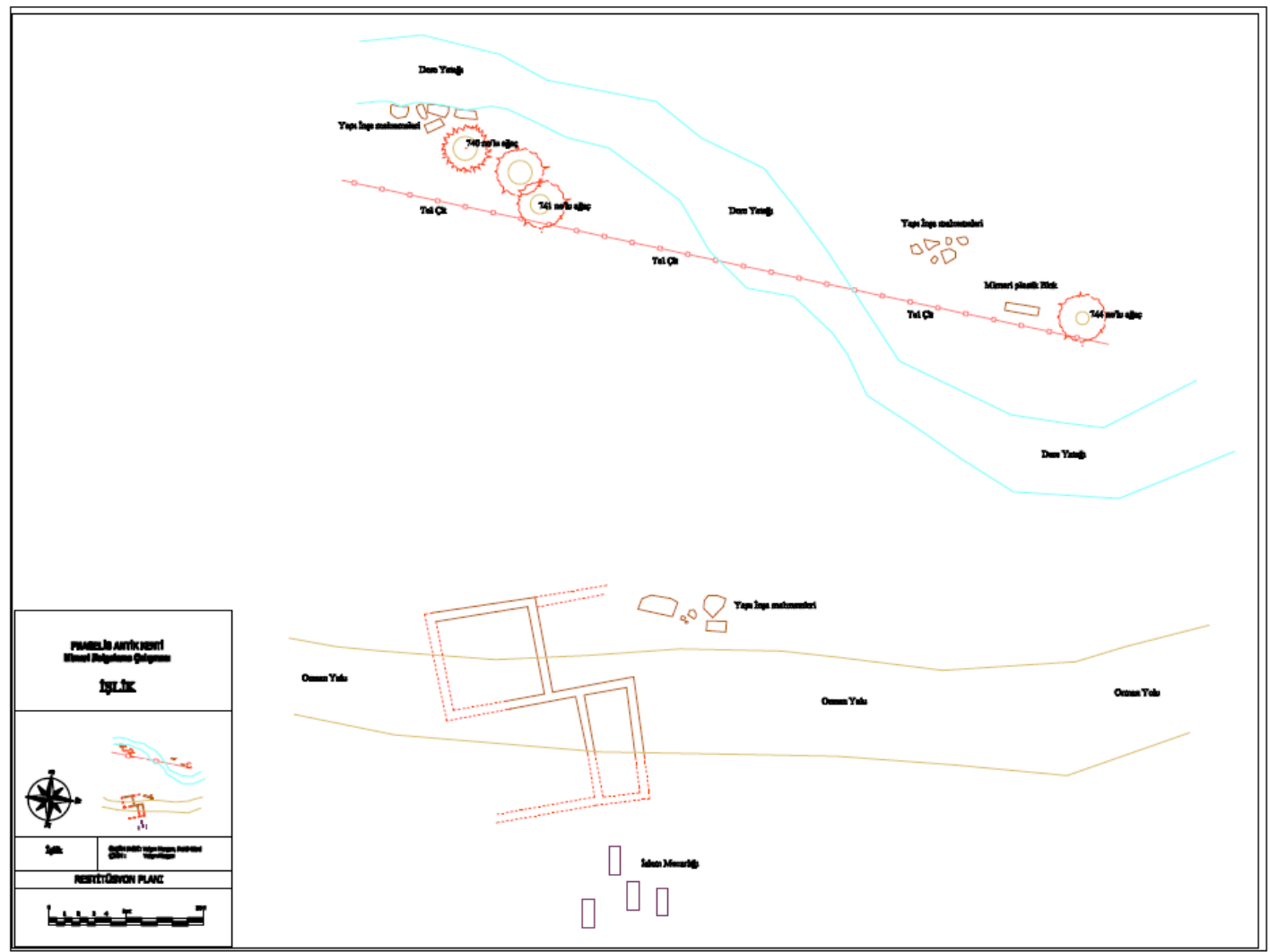

İşlik Yapı Topluluğu Restitüsyon Planı (Y. Mergen)
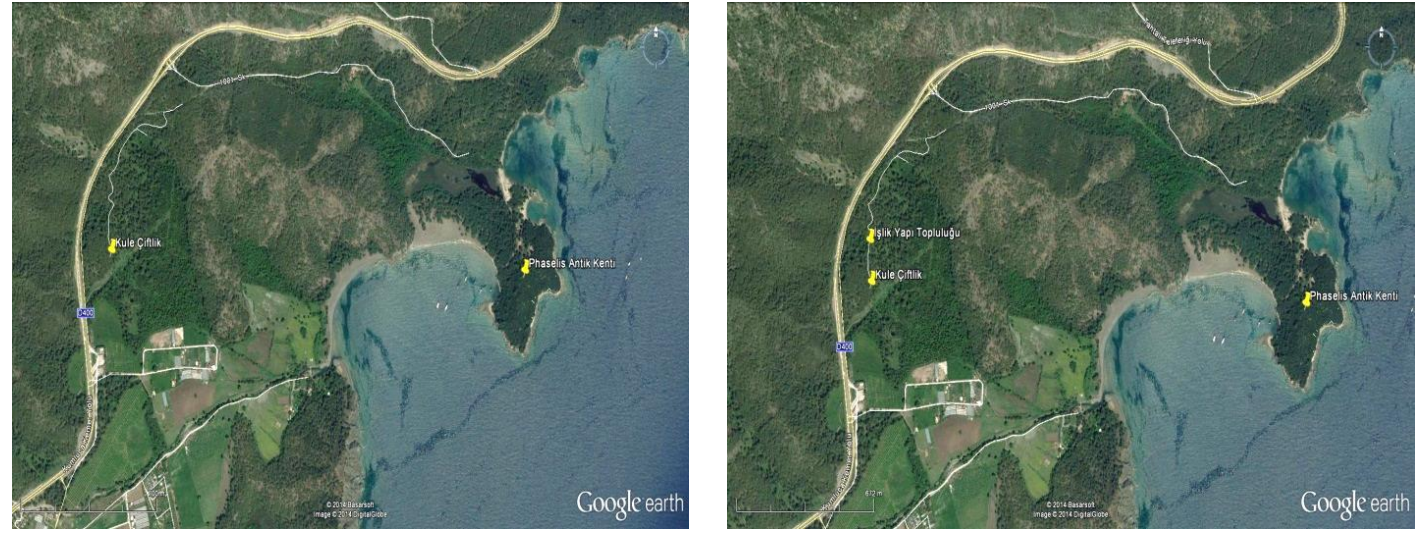

İşlik ve Kuleli Çiftlik Kalıntılarının Phaselis'e Göre Konumu

Ardından Mansio'dan başlayarak Çöğmen Tepe etrafını dolaşarak Bostanlı Koyu'ndaki İnciryalısı mevkiine doğru ilerleyen güney yoluyla birleşen güzergaha ait hassas ölçümler alınmış ve topografik haritamıza eklenmiştir.

(Bu yapı topluluğu ekibimiz üyesi Y. Mergen tarafından çalışımış ve ilgili rapordan yayarlanılmıştır). 


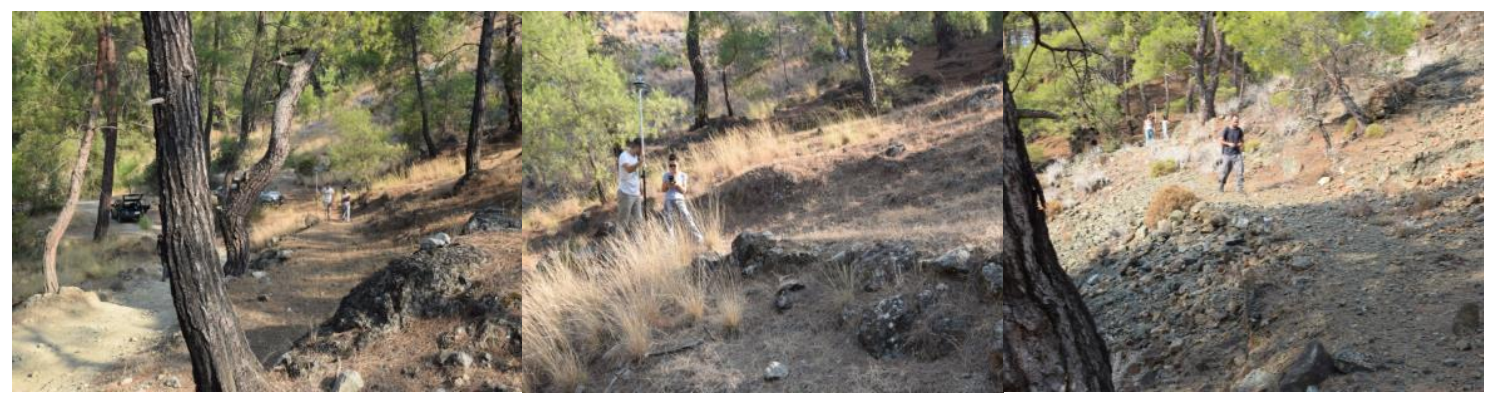

Çöğmen Tepe Etrafından Bostanlı Koyuna ilerleyen Güzergah (Güney Yolu?)

\section{B) Phaselis - Çamyuva Yol ve Savunma Sistemleri}

Antikitede nekropolis'ler (ölüler kenti) polis'in dışına kurulur ve mezarlıklar bu alanlarda sergilenirdi. Söz konusu gömü alanları zaman içinde genellikle kentlerin girişlerinde kalır ve kente doğru uzanan yol güzergahlarından bazıları bu nekropolis alanlarından geçerek kente ulaşırdı. Bu durum Phaselis açısından da benzer özellikler taşımaktadır.

Projemizin Phaselis-Çamyuva Yol ve Savunma Sistemleri kapsamında, kentin kuzey limanı ve çevresi ile lagün etrafındaki yerleşim dokusu ve kuzeydoğu ve kuzeybatı nekropolis'leri detaylı bir şekilde incelenmiştir. Araştırmalar sonucu elde edilen veriler doğrultusunda PhaselisTekirova güzergahına bağlı yol sistemine benzer özellikler taşıyan iki yol sistemi tespit edilmiştir. Bunları biri deniz kenarından -genellikle topografyaya uygun olarak-, kuzeydoğu nekropolis'inin içinden ilerleyen 'Phaselis-Çamyuva arası Sahil Yolu: Kuzey Yolu'; diğeri ise yer yer kuzeybatı nekropolis'inin içinden geçerek Çamyuva istikametine doğru giden 'Phaselis-Çamyuva arası Kuzeybatı Yol Güzergahı' şeklinde sınıflamak ve bu doğrultuda mercek altına almak mümkündür.

\section{B1) Phaselis - Çamyuva arası Sahil Yolu: Kuzey Yolu}

Phaselis'in Çamyuva ve üzerinden Idiros (Kemer?) istikametine giden güzergahı -ya da bu güzergahlardan biri- kuzeydoğu nekropolis'i arasından ilerlemekteydi. Phaselis'in üçüncü ve en büyük nekropolis'i olan kuzeydoğu mezarlığı kentin doğu girişindeki kuzey limanı ile lagünün önlerinden başlayıp Alacasuya kadar yak. $2 \mathrm{~km}$ boyunca devam etmektedir. Önceki yıllarda yapılan araştırmalar sırasında Phaselis'in yakın hinterlandı ve diğer yerleşimlerle olan bağlantısını sağlayan ulaşım ağının tespiti konusundaki ön incelemelerden hareketle kentin kuzey limanından itibaren kuzeydoğu nekropolis alanı boyunca Inceburun, Cennet Koyu olarak adlandırılan koy ve Karaburun istikametinden Alacasu'ya oradan da Sarı̈ren Tepesi üzerinden Çamyuva'ya doğru ilerleyen güzergahlar araştırılmış, kontrol edilmiş, belgelenmiş ve hassas koordinatları alınarak topografik haritamıza işlenmiştir.

Hellenistik Yerleşim'deki kapıdan merdivenler eşliğinde inen ve kuzeydoğu nekropolis'in içinden geçerek bir kolu kente, diğer kolu ise Alacasu istikametine doğru ilerleyen yol yer yer takip edilebilmektedir ${ }^{27}$. Alanda şimdiye kadar herhangi bir kazı çalışması gerçekleştirilme-

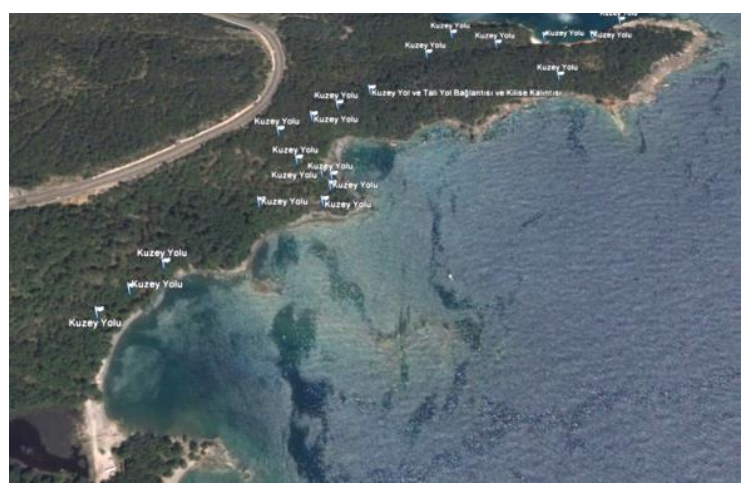

Kuzey Limanı ile Inceburun Arasında Kuzeydoğu Nekropolis'inden Ilerleyen Sahil Yolu

27 Bayburtluoğlu 2004, 81 vd. 
diğinden söz konusu güzergahta cadde-sokak düzenlemelerine ilişkin bir gözlem yapılamamakla birlikte antik güzergahların yer yer mezar öbekleri arasından ilerlediği tespit edilebilmektedir ${ }^{28}$. Bu güzergahların genişliğinin bazı alanlarda 3 m’ye ulaştığı belgelenmiştir.

Güzergah üzerinde bir rezervuar alanı, bir kilise ile biri olası bekçi kulübesi olmak üzere nekropolis'le ilintili birkaç yapı kalıntısı tespit edilmiştir. Ancak kuzeydoğu nekropolis'indeki kentin rezervuar alanını geçinceye kadar herhangi bir yol kalıntısı tespit edilememiştir. Ancak rezervuar alanının yaklaşın $150 \mathrm{~m}$ güneyinde, yola ait istinat duvarları görülmüş ve yaklaşık $150 \mathrm{~m}$ boyunca takip edilebilmiştir. Inceburun mevkiini geçtikten sonra Cennet Koyu'na doğru yer yer ilerleyen yol kalıntılarına rastlanılmıştır. Cennet Koyu denilen mevkide daha önce de tetkik ettiğimiz olası güzergah yeniden kontrol edilmiştir. Olası güzergahın İskender'in Phaselis'ten Perge'ye doğru ilerlerken kullanmış olabileceği yolla bağlantılı olabileceği düşünüldüğünden fotoğraflanmış, hassas gps koordinatları alınmış ve olası güzergahın devamı araştırımıştır.

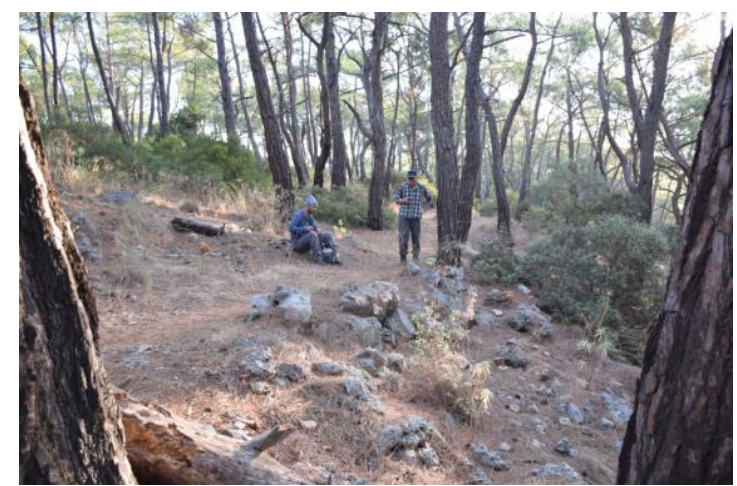

Kuzeydoğu Nekropolis Yolu

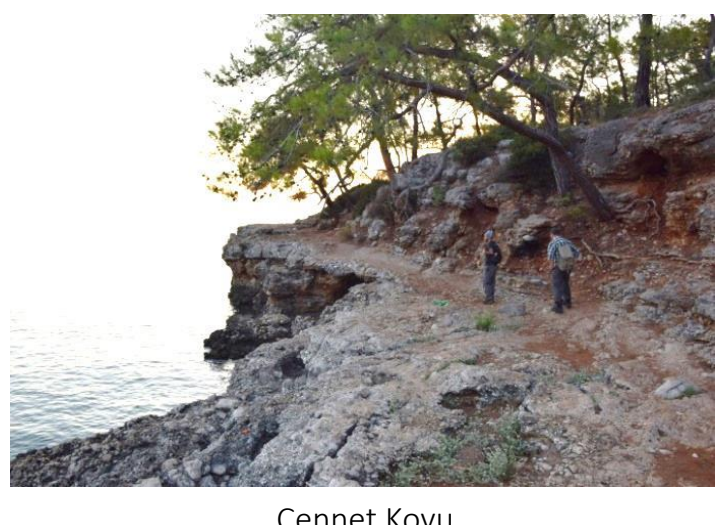

Cennet Koyu

Söz konusu güzergah Alacasu istikametine doğru takip edilmiştir. Ancak bu arada kesin olarak belgelenebilecek herhangi bir yol kalıntısı saptanamamıştır.

Ardından söz konusu yolun sahilin hemen kuzey doğusundaki tepenin eteklerinden devamı da tetkik edilmiştir. Daha önceki dönemlerdeki çalışmalarda bir bölümünü tespit edip belgelediğimiz güzergahın Alacasu'yun kuzey doğusu boyunca uzanan Sarıören Tepesi üzerinden Çamyuva istikametine kadarki kısmının tekrar üzerinden geçilerek güzergaha ilişkin yeni eklemeler ve düzeltmeler yapılmıştır. Bu yolun Çamyuva'daki Robinson Crusoe Oteli'nin çitlerine kadarki kısmı büyük ölçüde takip edilerek hassas ölçümleri alınmış ve topografik haritamıza işlenmiştir. Bu şekilde yer yer kesintilerle de -özellikle vadi yataklarında- olsa Phaselis'in kuzeydoğu nekropolis'inden başlayarak Çamyuva'ya kadar devam eden Sahil Yolu güzergahı belgelenmiştir.

\section{B2) Phaselis - Çamyuva arası Kuzeybatı Yol Güzergahı}

Phaselis'in Kuzey Limanı'yla bağlantılı lagünün kuzeyinden itibaren kuzeybatı nekropolis'inin içinden geçerek ilerleyen güzergah Phaselis Araştırma İstasyonu karşısından devam etmektedir. Yer yer $4.5 \mathrm{~m}$ genişliğe sahip bu güzergah, modern Antalya-Kumluca karayoluna paralel bir şekilde yak. $250 \mathrm{~m}$ boyunca izlenebilmektedir. Ancak bu noktadan sonra modern yolun yapımı sırasında yoldan taşan molozların altında kalarak tahrip olmuştur. 
Güzergah kentin Hellenistik Yerleşkesi'ne doğru yaklaşılırken muhtemelen modern yolla birleşecek olmasına karşın büyük bir ihtimalle modern yolun altında kalmış gözükür. Bu noktadan itibaren modern tahribat son derece belirgindir. Yola ait olası verilerin bir bölümü modern Antalya- Kumluca otoyolunun kuzeybatısında yer yer takip edilebilse de bu güzergahla bağlantılı olup olamayacağı kesin değildir. Ancak söz konusu yola ait son derece kesin kalıntılara modern yoldan Alacasu Vadisi'ne doğru ilerlerken rastlanılmıştır. Vadinin etekleri boyunca zikzaklar çizerek ilerleyen bu güzergahın bir tarafı istinat duvarlarıyla tahkim edilmiş olup yer yer 3 m’ye varan genişliğe sahiptir.

Söz konusu güzergah Alacasu sahili yakınlarına kadar takip edilebilmiştir. Vadi içinde ve sahilde kaybedilen güzergaha ilişkin yapılan incelemeler sonucunda, bu yolun Alacasu vadisinin girişinde, Sarı̈ren Tepesi'nin güneybatı etekleri boyunca kuzeybatı yönünde ilerlediği ve Çamyuva'dan sonra iç kısımlardan Idyros (Kemer) istikametine doğru devam ettiği düşünülmüştür.

Yer yer 4-5 m genişliğe ulaşan yol, zaman zaman 2.5 m’yi aşan tahkimatla destekleniştir. Yaklaşık 300 $m$ boyunca takip edilebilen bu yol güzergahı Sarıören Tepesi'nin kuzey ucunda Antalya-Kumluca karayolu yapımı dolayısıyla tahrip edilmiş ve kesintiye uğratılmıştır. Buradan Çamyuva istikametinde sahile doğru ilerlemesi muhtemel yola ilişkin geniş çaplı araştırmalar yapılmış olsa da modern yol ve yoğun yapılaşma yüzünden herhangi bir kalıntılı tespit edilememiştir.

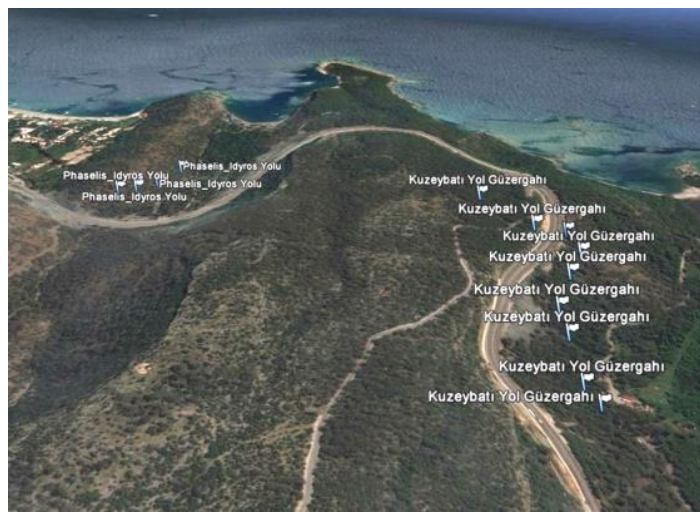

Kuzeybatı Nekropolis'inde Çamyuvaya Doğru İlerleyen Güzergah

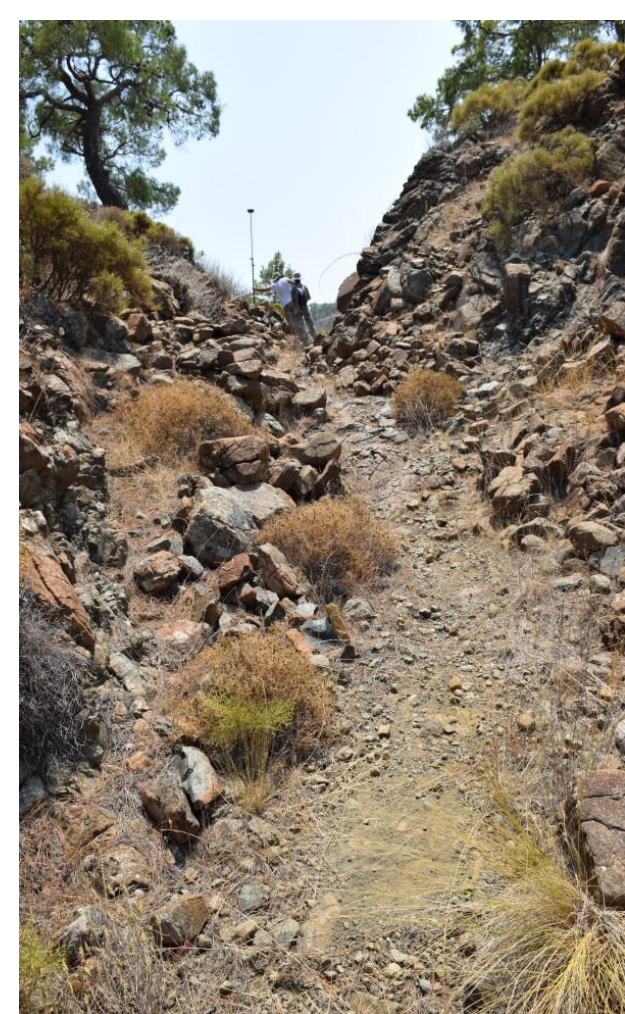

Sarı̈ren Tepesi Yol

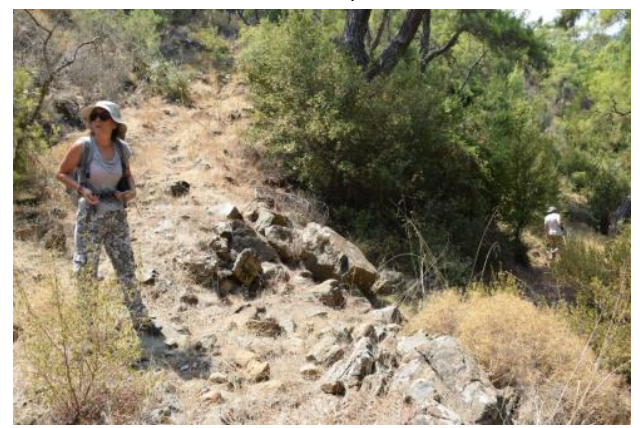

Alacasu'dan Sarıören Tepesine doğru ilerleyen Güzergah

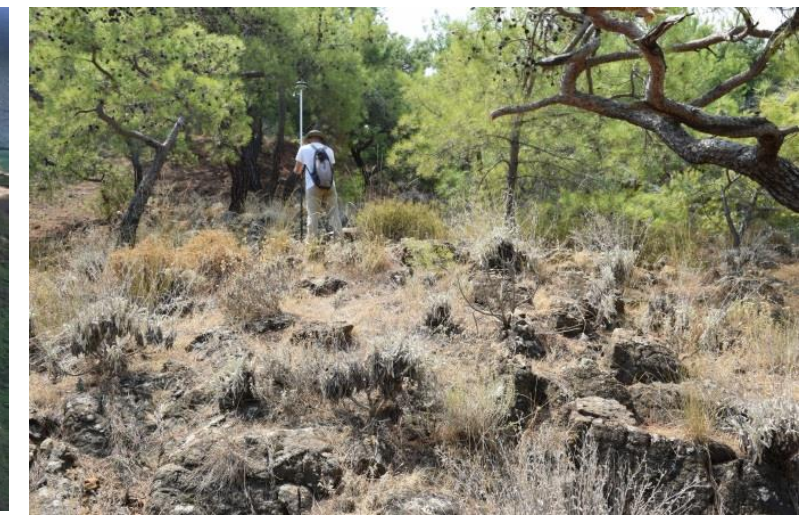

Antalya Kumluca Otoyolunun Kuzeybatısı'ndan Alacasu'ya İlerleyen Güzergah 


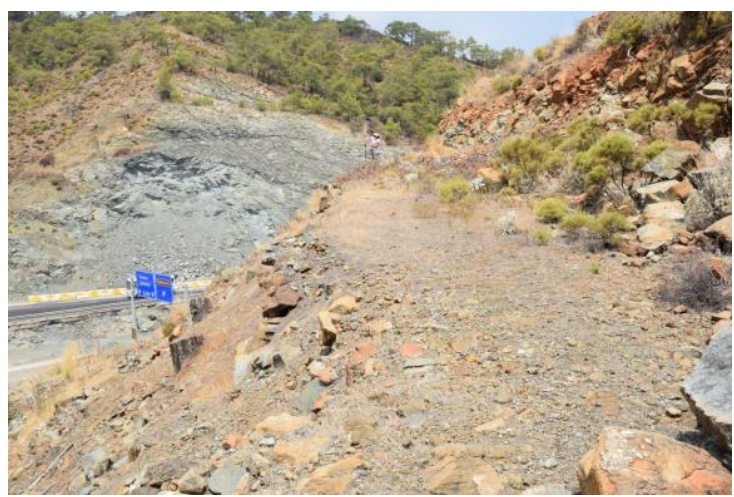

Phaselis-Çamyuva Arası Sarı̈ren Tepesinden ilerleyen Yol (Idiros? Yolu)

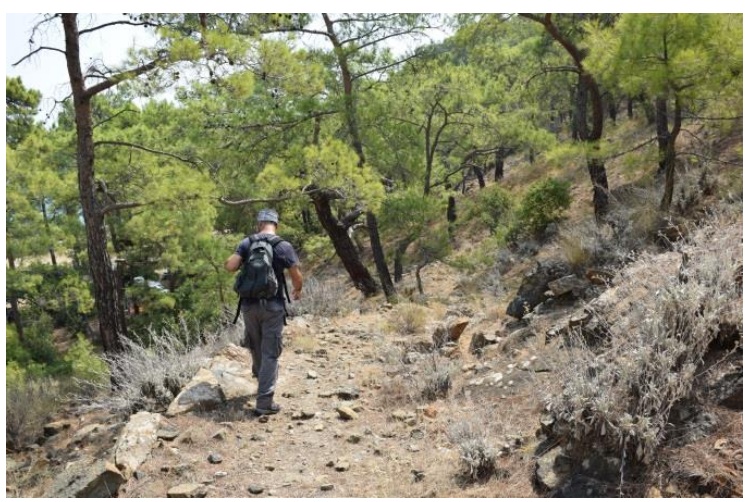

Antalya Kumluca Otoyolunun Kuzeybatısı'ndan Alacasu'ya İlerleyen Güzergah

\section{C) Phaselis (Hellenistik Yerleşim ve Kapısı'ndan) Olympos (Tahtalı) Dağı Yol ve Savunma Sistemleri}

Braudel'in de ifade ettiği gibi Akdeniz bir teraslar havzasıdır. Bu durum özellikle Anadolu Akdeniz'i açısından geçerlidir. Kıyıya paralel yükselen dağlar tarımın teraslar ve polyelerde yapılmasına olanak sağlamaktadır. Phaselis açısından da durum böyledir. Phaselis konumu itibariyle sırtını Tahtalı Dağı'na dayamıştır. Denizden yak. 15 km sonra rakım 2360 m'ye ulaşmaktadır. Akdeniz'in hiçbir yerinde deniz seviyesinden bu kadar yükseğe bu kadar kısa mesafede ulaşılamamaktadır. Bu da Phaselis'in yakın çevresinin eğim seviyesini artırmaktadır. Bu yüzden gerek kent içinde gerekse teritoryumda bulduğumuz hiçbir yol araba taşımacılığına uygun olarak inşa edilmemiştir. Phaselis'in yakın çevresiyle ve Tahtalı Dağı istikametindeki bu güzergahlar daha çok yaya ve yük hayvanlarının emtia trafiğine sahne olmuş gözükür. Yani ürünler daha çok, eşek, katır, at gibi hayvanlarla taşınmış olmalıdır. Elde ettiğimiz verilerde yol genişliklerinin yer yer 3-4 m’ye varsa dahi eğim ve coğrafya araba kullanımına izin vermemiştir.

Phaselis'in yol güzergahlarına, su ve savunma sistemine yönelik araştırmalar ile kırsal yerleşimlerin (polikhnikon-kome) tespiti çalışmalarına 2012 yılından itibaren devam edilmektedir. Bu doğrultuda kentin Hellenistik Yerleşimi olarak adlandırılan ve burada konuşlandırılan kuzey kapısı üzerinden Tahtalı Dağı'nın doğu eteklerine ulaşan yoğun bir iletişim ağı vardır. Bunda topografyanın etkisi büyüktür. Çünkü Phaselis'in etrafı yer yer 50 m'yi bulan falezlerle çevrelenmiştir. Tahtalı (Olympos) Dağı’nın doğu eteklerinden kente giriş için tek uygun konum ve kapı Hellenistik Yerleşim olarak tanımlanan kentin kuzey yerleşiminde yer almaktadır ${ }^{29}$. Bu iletişim/yol ağı kentin yakın hinterlandı çerçevesinde yer alan daha sayısını belirleyemediğimiz çiftlik yerleşimleri, mahalleler, köyler, kentçikler özelinde anakent (metropolis) ile teritoryumunu birbirine bağlar. Bu girift ilişkinin sosyal, siyasal ekonomik ve kültürel boyutları vardır.

29 Bu durum kentin yol ağı, savunma sistemi kadar, topografyanın hidrografik yapısı ve su sistemiyle de doğru orantılıdır. Konuya ilişkin olarak ayrıca bk. Tüner Önen - Akçay 2014, 287; Kürkçü 2016, 107. 


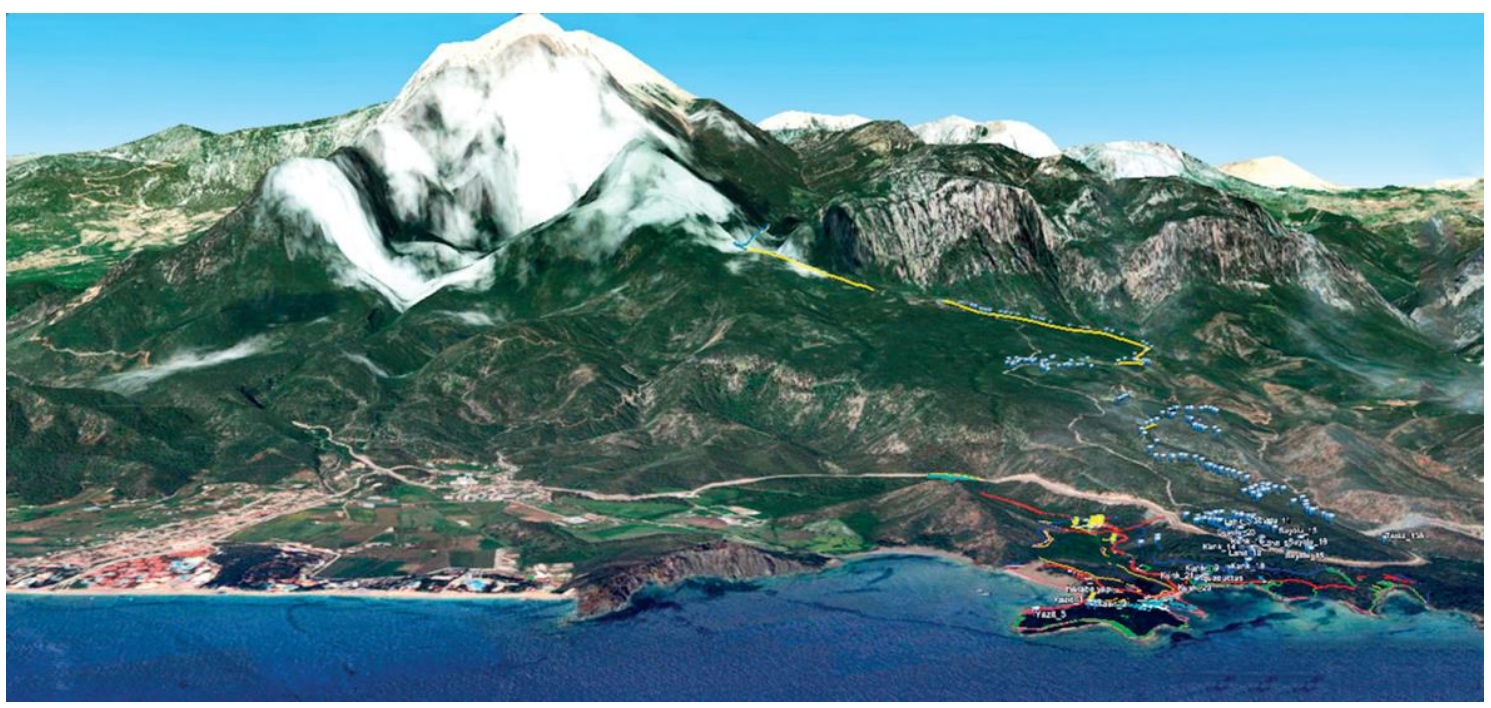

Phaselis ile Tahtalı İstikameti Arasında Belgelenen Arkeolojik Materyal Kültür Kalıntıları (Google Earth)

Olympos (Tahtalı) Dağı istikametinde yapılan tarihsel coğrafi araştırmalar sırasında bu bölgenin Tahtalı istikametinde teraslamalar yapılarak tarımsal üretim amaçlı: özellikle zeytin ve üzüm yetiştiriciliği ile zeytinyağı ve şarap ticareti için kullanıldığı tespit edilmiştir. Söz konusu lokasyonda yer alan kentçik, köy, kasaba, kuleler, çiftlik evleri, işlikler, mezar alanları ve materyal kültür kalıntıları Phaselis'in hemen batısında yükselen Tahtalı Dağ eteklerinin kentin yakın çevresi olarak kırsal üretim faaliyetlerinde yoğun bir şekilde kullanıldığını ve yerleşim yeri olarak iskan edildiğini göstermiştir. Kentin ekonomi tarihine ve ihracatına ışık tutan, teritoryumunda tespit edilen yeni arkeolojik kalıntılar envanterlenmiş, hassas gps koordinatları alınarak uydu fotoğrafları üzerinde yerlerine yerleştirilmiştir.

Phaselis'in Hellenistik Yerleşimi'nin hemen üstünden başlayarak Tahtalı Dağ eteklerine kadar sürdürülen çalışmalar, kentin Tahtalı Dağı'nda yer alan kaynaklardan sağlanan su teminine ilişkin kalıntılar sayesinde belirlenen suyolu güzergâhının belirli oranda bununla ilintili servis yoluyla paralel şekilde ilerlediğini göstermiştir. Alanın topografyaya uygun bir şekilde teraslanarak tarıma elverişli hale getirilmesine paralel olarak gerek bahçelerin sulanması gerekse kentin su intiyacının karşılanması için çoğunlukla künkler yardımıyla değişik lokasyonlardan kentin aquaeductus'una su taşındığı tespit edilmiştir. Su daha çok Tahtalı Dağ eteklerindeki kaynaklardan ve derelerden sağlanmış, zaman zaman da sarnıçlar yoluyla biriktirilerek temel ihtiyaçlar için kullanılmış görünür. Yapılan araştırmalara göre Tahtalı Dağı'nın doğu eteklerindeki Tamtır Alanı olarak adlandırılan mevkiinin yak. 200 m kadar üstünde, Mağara Deliği yakınındaki dar kayalıklardan çıkan kaynak, Tamtır Alanı'ndan künklerle Sızgılı Kaya, Akboyun, Haruplu Boyun ve Yerleştir Sırtı mevkilerine iletilmektedir. Kale mevkiinin güneybatısında tespit edilen ve yer yer 3,5 m yüksekliğe kadar ulaşan, polygonal taşlardan örme suyoluna ulaşılmaktadır. Burada tespit edilen suyolu yaklaşık 70 m kadar Phaselis yönünde doğuya doğru takip edilebilmektedir. Yerleştir Sırtından itibaren Telefon Gediği Alanı'na ve Kuzey Yerleşimin Antalya-Kumluca Otoyolu tarafından kesintiye uğradığı noktaya kadar tespit edilen künk kalıntıları düz bir hat oluşturmaktadır. Kuzey Yerleşimin kuzeybatısından itibaren kentin Kuzey Limanı'na doğru yönelmiş çok sayıda su aktarım kalıntısı tespit edilmiştir. Bu alanda, kaynaklardan toplanan sular künklerle 
aquaductus yapısına iletilmiştir ${ }^{30}$. Söz konusu hattın hemen kenarından su yoluna paralel bir şekilde ilerleyen bir güzergah tespit edilmiştir. Bu güzergah bir yandan servis yolu olarak hizmet verirken diğer taraftan da bir patika şeklinde Phaselis'in hinterlandıyla olan iletişimini sağlayan birçok güzergahtan biri olarak kullanılmış olsa gerektir. Güzergah haritada çift çizgi arasındaki kırmızı hat olarak gösterilmiştir.

Diğer bir güzergah ise Akboyun alanından başlayarak Harputlu Boynu'na doğru ilerlemektedir. Tahtalı Dağı'na çıkan teleferik istasyonunun hemen doğusundan (Akboyun Alanı'ndan) Phaselis istikametine (Harputlu Boynu'na) doğru ilerleyen antik yol güzergahı yaklaşık $5 \mathrm{~km}$ boyunca izlenmiştir. Antik güzergahın doğu-kuzeydoğu yönü yer yer kireçtaşı bloklarla örülmüştür. Söz konusu güzergahın ve yol kenarında yer alan terasların lokalizasyonları belirlenmiş ve belirli aralıklarla fotoğraflanarak gps koordinatları alınmıştır. Güzergahlar ve terasların gps koordinatları topografik haritaya işlenmiştir.

Tahtalı Dağ eteklerinde yürütülen çalışmalarda aynı zamanda kentin savunma sistemine ve yerleşim arkeolojisine yönelik arkeolojik kültür kalıntıları da tespit edilmiştir. Bunlar arasında bölgenin Kale mevkiine doğru ilerleyen köy kısmında çiftlik yerleşimlerine ait olabilecek yapı kalıntısı, mezar ve teraslar içeren küçük bir yerleşim alanı dikkat çekmektedir ${ }^{31}$.

Phaselis istikâmetine doğu ilerleyen teraslar şeklinde planlanmış olan yerleşimin Helenistik ve Roma dönemlerinden geç antikçağa kadar kesintisiz olarak iskan edildiği saptanmıştır. Söz konusu yerleşim alanın kuzeyinden geçen teleferik yolunun kuzey tarafındaki tepelik alanda ise bir kule yapısı ve bu kuleyle bağlantıı yapı kalıntıları bulunmaktadır ${ }^{32}$. Söz konusu kule gerek ekibimiz $^{33}$ gerekse ekibimizden önce Beydağlarında Yüzey Araştırması yapan ekip tarafından bulunmuş ve çalışılmışıı ${ }^{34}$.

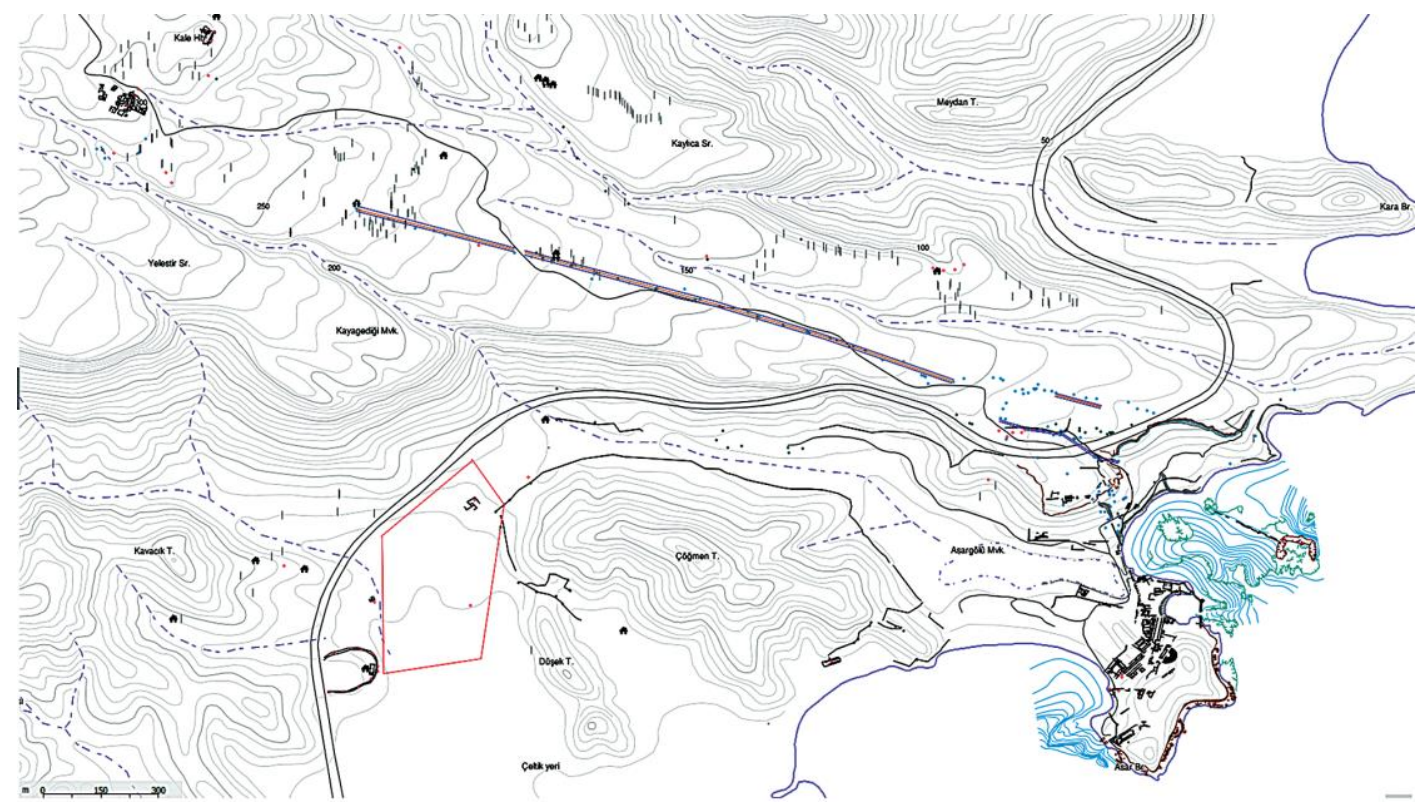

Phaselis Su Temin Sistemine Ait Koordinat Noktalarını Gösteren Topografik Harita (F. Demir)

30 Arslan - Tüner Önen 2013, 292 vd.; 2016, 72.

31 Arslan - Tüner Önen 2016, 73.

32 Arslan - Tüner Önen 2016, 73.

33 Arslan - Tüner Önen 2014b, 293 vd.

34 Kızgut 2017, 199 vdd. 

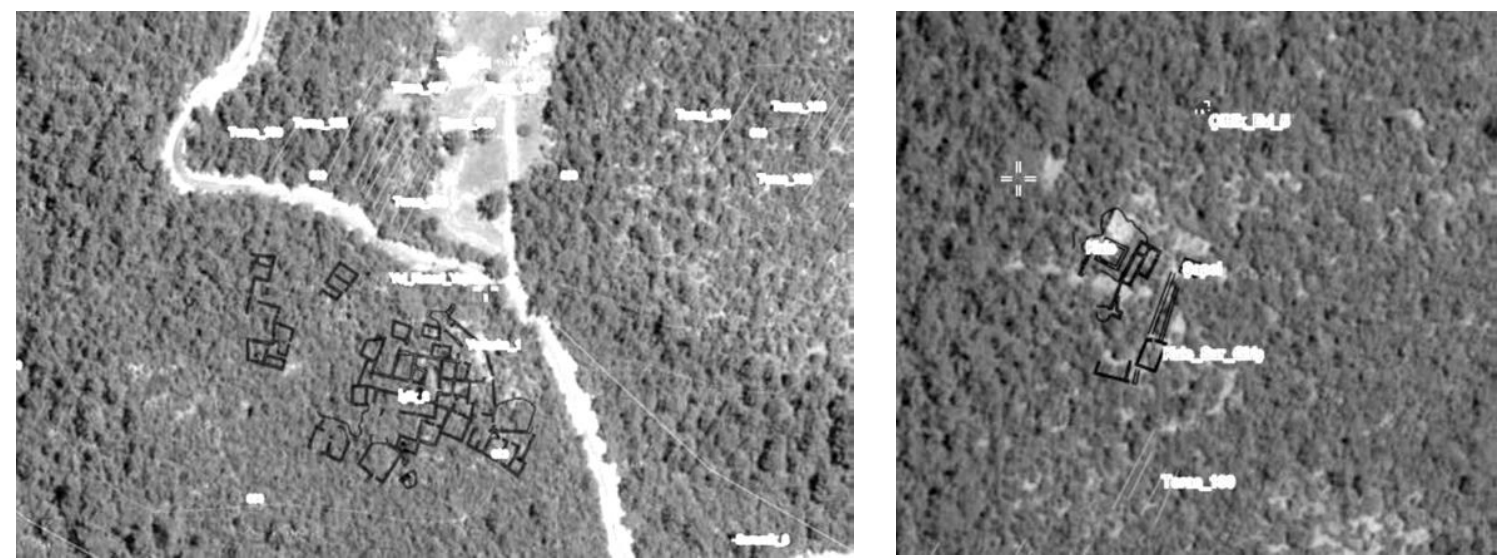

Yerleştir Sırtı'nın Kuzeyinde Yer Alan Küçük Yerleşim

(Plan, Beydağları Yüzey Araştırmaları Arşivinden Alınmıştır)

Gökgür alanında yer alan bu kule gerek kentin gerekse iskan edildiği mevkideki çiftlik ve yakınlarındaki köy yerleşiminin savunmasına yönelik inşa edilmiş olmalıdır ${ }^{35}$. Zira Gökgür alanından Phaselis istikametine doğru yaptığımız incelemeler sırasında düzinelerce teraslama, 1'i son derece tahkimli ve iyi korunmuş olmakla birlikte 2 tane çiftlik kompleksi tespit edilmiştir. Diğer çiftlik evi ise Gökgür Deresi'nin hemen üzerindeki tepenin eteklerinde 3-4 tane yapı kompleksi şeklinde doğu batı istikametinde konuşlandııımıştır. Ancak son derece yoğun dikenli bitki örtüsü nedeniyle detaylı planını çıkartmak mümkün olmamıştır. Söz konusu çiftlik evinin hemen 50-100 m yukarısındaki tepe üzerinde Hellenistik Kule olarak adlandırılan tahkimli yerleşim tetkik edilmiştir. 3 kattan fazla olması gereken kulenin ilk katı her ne kadar düşen taş bloklar ve toprakla dolmuş olsa da halen yak. $5 \mathrm{~m}$ yükseklikte bozajlı çift sıra dikdörtgen bloklardan yapılmış $140 \mathrm{~cm}$ genişliğe varan duvar örgüsüyle ayaktadır. Zaman içinde doğal aşınım, kaçak kazılar ve depremlerden zarar gören 680 cm'ye x $650 \mathrm{~cm}$ (içten içe) ölçülerindeki yapının durumu görülmeye değer bir spekturum içermektedir. Kulenin duvarları üzerinden doğuda,

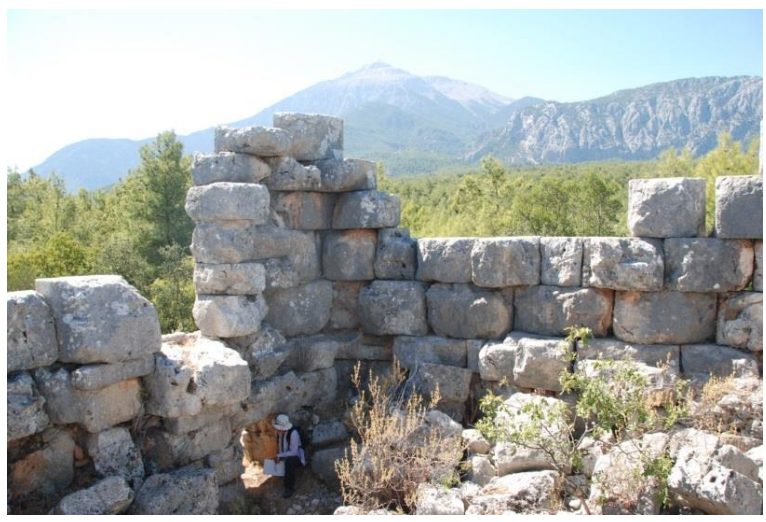

Gökgür Alanı, Hellenistik Kule Pamphylia, Pisidia, Kilikia Trakheia, batıda Lykia'nın büyük bir bölümü, kuzeyde ve kuzeybatıda Pisidia'nın içlerine kadar görülebilmektedir ${ }^{36}$. Phaselis ile direk bağlantılı görülen tahkimli yapı aynı zamanda Akboyun'daki yerleşimle direkt iletişim halindedir. Son derece hakim konumu ile Akdenizi panoramik olarak çok uzaklara kadar kuşbakışı gözetlemektedir. Yapının çevresinde yaptığımız incelemeler sırasında kuleye ait Hellenistik Dönem'de kullanılan teraslamalar, dış duvarlar ve yerleşimler olduğu tespit edilmiş ve kompleks yapı zinciriyle birbirine

35 Çünkü bölge antik kaynaklardan da bilindiği üzere Geç Klasik ve Hellenistik Dönem'in başlarından itibaren haydut ve yağmacıların baskınlarına açıktı. Hatta MÖ 333 yılında Büyük İskender Phaselis'teyken Mnaralıların (Marmara) bu tarz saldırılarından bıkan Phaselisliler şikayetlerini İskender'e bildirmişler kral da ordusunun hafif silahlı askerlerinden oluşan birliklerini göndererek Mnaralıları cezalandırmıştı.

36 Ayrıca bk. Arslan - Tüner Önen 2014b, 293 vd. 
bağlandığı gözlenmiştir. Söz konusu alan daha sonra geç antik dönemde de yerleşim görmüş ve kulenin yak. $30 \mathrm{~m}$ güneydoğusunda yak. $5 \mathrm{~m}$ ölçülerinde, $70 \mathrm{~cm}$ kalınlığındaki duvar örgüsüne sahip bir şapel kalıntısı tespit edilmiştir. Doğuya bakan şapelin kuzey batı duvarında iki niş açılmış olup burada harç ve sıva izlerine rastlanmıştır. Aynı şekilde yapının hemen pronaos kısmında da güneybatı çıkıntısında at nalı şeklinde iki niş izi tespit edilmiştir. Kaçak kazılar tarafından her ne kadar tahrip edilmiş de olsa nişler açık bir şekilde izlenebilmektedir.

Kule ve çevresinde yaptığımız çalışmalar sırasında da birçok yapı ve düzinelerce teras tespit edilmiştir. Kule bulunduğu konumu itibariyle bir yandan Akboyun'daki teleferik istasyonunun yanındaki, en azından Geç Klasik Dönem'den ${ }^{37}$ itibaren yerleşim gören tahkimli kentçiği ${ }^{38}$ (polikhne)

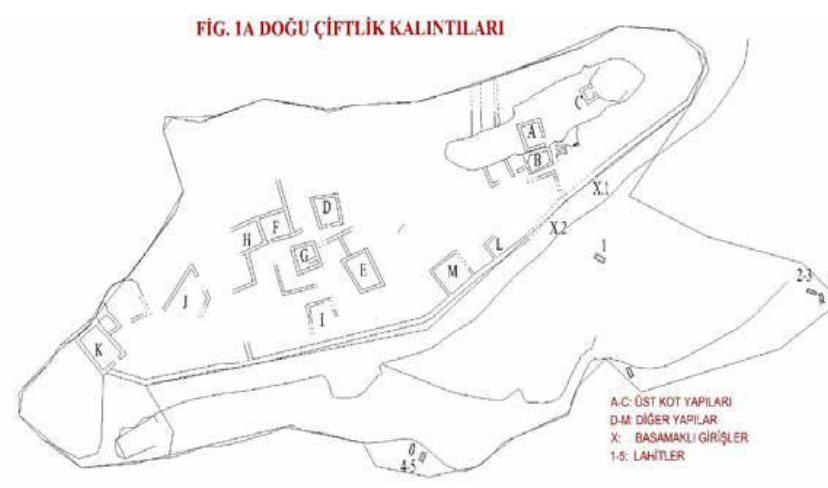

Poliknihon, İsa Kızgut, 2017 Cedrus V (199-215) 201 Fig 1

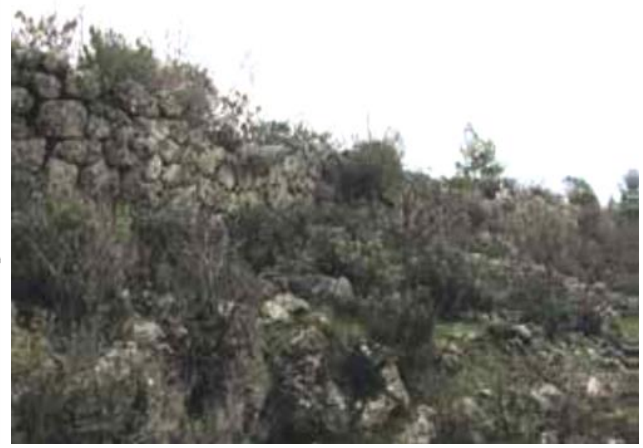

Poliknihon İsa Kızgut, 2017 Cedrus V (1992015) 201 Fig 3

kuşbakışı görmektedir. Aynı bu şekilde Akboyun'daki bu yerleşim de Gökgür alanındaki yerleşimle bir yandan benzeşirken bir yandan da ondan ayrılmaktadır. Benzeşme tarım ve hayvancılık

37 Kentciğin polygonal duvar işçiliğinin stil-kritik açıdan değerlendirilmesi sonucu kesin olmamakla birlikte Geç Klasik Hellenistik Dönem'e tarihlendirilebileceği düşünülebilir.

Teleferik istasyonunun konuşlandırıldığı Akboyun'un yak. 20 m doğusunda polygonal kireç taşından ana kaya üzerine inşa edilmiş Hellenistik Dönem'e tarihlendirilebilecek bir akropolis yer almaktadır. Her ne kadar daha önceden burası bir tahkimat/kule/kale gibi adlandırmalarla isimlendirilmişse de yaptığımız incelemeler sonucu Hellenistik Dönem'e tarihlendirilebilecek bir akropolis olabileceği saptanmıştır. Zira, akropolis'in güneydoğu ve güney istikametleri, yak. $300 \mathrm{~m}$ boyunca geç antikçağa değin iskan alanı olarak kullanılmıştır. Harçlı yapılar kadar Roma Dönemi’nde de kullanılmış ikametgahların mimari planları yoğun bitki örtüsüne rağmen açıkça izlenebilmektedir. Yerleşimin nekropolis alanında ise genellikle khamosorion tarzı gömü gerçekleştirilmiştir. Ana kayaya açılan mezarlar düz damlı olup bazen tek kişilik bazen de aileye aittir. Yerleşimin hemen eteklerinden ise, Phaselis istikametine doğru devam eden taraçalar şeklinde düzinelerce teraslama tespit edilmiştir.

Yörede yaptığımız incelemelerde terasların yoğunlukta olduğu alanların yakınlarında çiftlik evleri ve çiftlik kompleksleri tespit edilmiştir. Çiftlik evlerinin genel itibariyle tahkimli üç ile beş odalı kompleksler olup, karakteristik olarak büyük ölçüde iyi işlenmiş kesme taşlardan inşa edildiği ve kaya temeller üzerine oturtulduğu gözlemlenmiştir. Çiftlik evlerinde yoğun seramik buluntulara rastlanılmaktadır. Evlerde çeşitli formlarda seramikler ile genellikle deve tüyü renginde, günlük kullanıma ait (bazen sırı) seramiklerle daha kaba formlarda depolama amaçlı amphora parçaları ve kulpları yer almaktadır. Bu komplekslerin içinde ve çevresinde ayrıca çatı kiremitleri bulunmaktadır. Ayrıca Gökgür alanında tespit ettiğimiz üzere kayaya oyulmuş işlikler hemen çiftlik evlerinin yanında (zeytinyağı) işlikleri de büyük ölçüde korunmuş şekilde yer almaktadır. Yaptığımız incelemeler sonucu söz konusu teraslamaların bazılarının antikçağdan itibaren kullanımının devam ettiği ve bazı yerlerde halen antik teraslamalara eklemeler yapılarak kullanılmaya devam edildiği örnekler de mevcuttur.

38 Burası aynı zamanda kırsal bir üretim merkezi olarak da kabul edilebilir. 
içerikli bir yerleşimin savunulması ve gözlem amaçlı olmasıdır. Farklıık ise Akboyun'daki kentçiğe ya da büyük ölçekli yerleşime ait yapıların hemen hemen hepsi bir tahkimli bir kayalığın üzerinde konuşlanmış olmalarıdır. Gökgür alanındaki kule ise yerleşim yerinde -ufak ölçekli bir köyyaklaşık 300 m uzakta olmasıdır. Ayrıca burası daha çok tarıma elverişliyken Tahtalı Dağı'nın eteklerindeki kentçik konumu ve topografya uyarınca ise daha çok hayvancılık merkezli olmalıdır. Bu durum her iki alanın çevresinde yaptığımız yüzey araştırması sonuçlarıyla da uyuşmaktadır. Zira Kule'nin etrafı daha geniş düzlüklerle ve geniş teraslarla çevriliyken kentçiğin bir tarafı uçurum diğer tarafı Tahtalı Dağı etekleri, Phaselis'e bakan tarafı ise görece dik teraslarla çevrilidir.

Gökgür alanındaki kulenin hemen hemen aynısı Phaselis'teki Hellenistik Yerleşim'in eteklerinde de tespit edilmiştir. Aynı mimar ve ustanın elinden çıktığı düşünülen bu tarz kule formları bu tarz savunma sistemlerinin merkezi bir otoritenin elinden çıkmış olduğunu kanıtlamaktadır. Benzer taş örgüsü ve ölçülere sahip bu yapılar Phaselis'in en azından Hellenistik Dönem'den itibaren hinterlandının sağlam bir savunma ağıyla çevrildiğine delalet etmektedir.

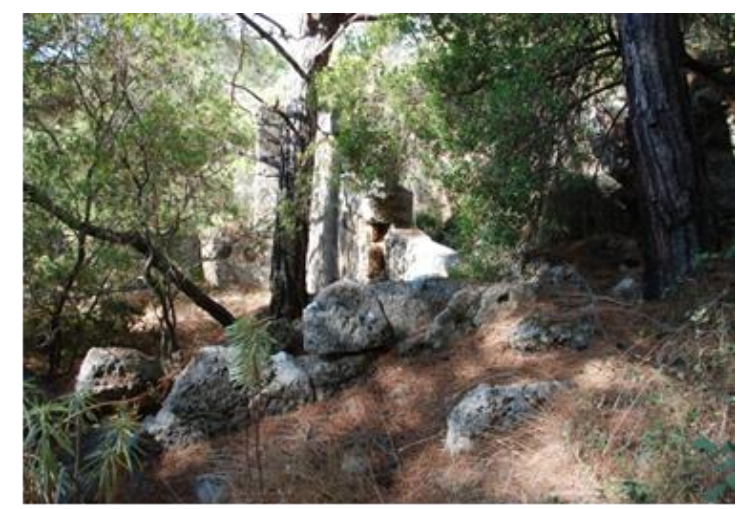

Hellenistik Kule

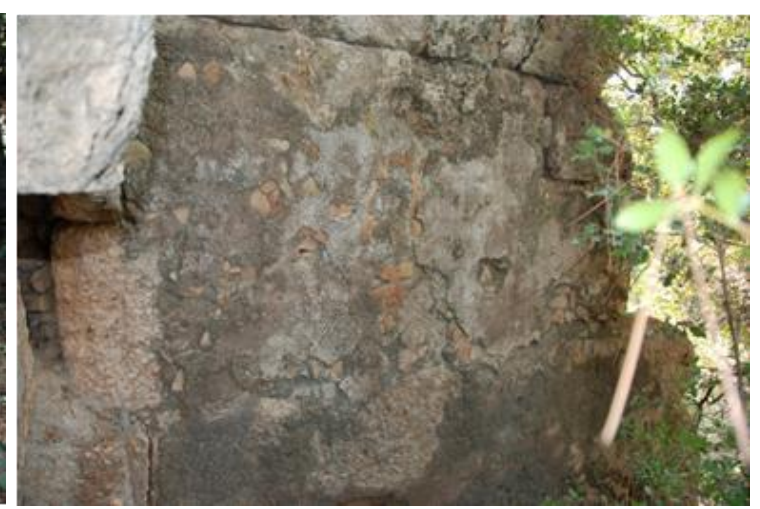

Hellenistik Kule, Sıva Örneği

Phaselis'te, Hellenistik Yerleşimi'nin eteklerinde yer alan kule modern Antalya-Kumluca otobanının altında konuşlandırımış olup hemen doğusunda teraslar yer almaktadır. Kulenin temeli ana kaya üzerine oturtulmuş olup, bir sırası iki sıra yan yana dikey, bir sırası yatay örülmüş büyük ebatlı, düzgün kesilmiş, yer yer bozajlı bloklarla örülmüştür. Kulenin iç kısmında yer yer geç antikçağda kullanımı gördüğünü gösteren sıvalı bölümler korunmuştur.

Kulenin iç duvarlarında (kuzeybatı ve kuzeydoğu) mermer sıvalı ve bozajı duvar örgüsünü andıran yaklaşık $120 \mathrm{~cm} \times 100 \mathrm{~cm}$ ölçülerinde 2-3 cm'lik duvar sıvası yer almaktadır. Ayrıca yapının girişinin güneydoğusundaki duvar üzerinde kiremitlerden yapılma duvar sıvası mevcuttur. Yapının duvar kalınlığı $70 \mathrm{~cm}$ ile $120 \mathrm{~cm}$ arasında değişmektedir. Giriş kapısı güneydoğuda yer alır. Girişin sağında küçük bir mekan, solunda ise büyük ana mekan vardır. Güneybatıdaki ana mekan dikdörtgen planlı olup, girişin karşısında yer alan duvar dışarıya doğru dikdörtgen bir çıkıntı yapmaktadır. Bu çıkıntının üst kısmındaki büyük ebatlı bloğun üst kısmı dikdörtgen formda 6-7 cm derin oyulmuş olup, iç cephesi derzli, sıva kalıntıları vardır. Ayrıca mekanın güneydoğu duvarının ayakta kalan kısmında ve seramik parçalarıyla kaplanmış bölümün iç cephesinde sıva vardır. Sıva gri renkli ve kumlu şamat katkılı (seramik parçalı) geç dönem özellikleri gösteren niteliktedir. Bu yapının güney köşesi ve güneydoğu ile güneybatı bölümü büyük oranda yıkılmıştır. Duvarlarda derin ayrılmalar vardır. Yıkılan duvar blokları yamaçtan yuvarlanmıştır. Girişin sağında ve yapının doğu köşesindeki mekanın kuzeydoğudaki girişinin karşısındaki duvar cephesi içinde küçük dikdörtgen bir niş (yük. $73 \mathrm{~cm}$; gen $51 \mathrm{~cm}$; der. $42 \mathrm{~cm}$ ) vardır. Girişin önündeki alan her iki mekanın girişlerinin açıldığı bir koridor niteliğinde olup yapının kuzey köşesindeki alana doğru ilerle- 
mektedir. Ancak bir alanda mevcut olabilecek mekan ya da koridor bölümü yoğun heyelan yığını ve kayalarla dolduğu için kesin olarak tespit edilememiştir. Kısmen doğal heyelan ve kısmen de Kumluca-Antalya otoyolu yapımı sırasında yapılan dolgu çalışmasında aşağıya düşen kayalar yapıyı doldurmuş ve tahrip etmiştir. Yapının ana girişi önünde doğu köşeden güneybatıya doğru uzanan koridor biçiminde bir alan oluşturmak içim "L" biçimli büyük ebatlı kireçtaşı bloklardan polygonal bir duvar örülmüştür. Bu duvar aynı zamanda bir istinat duvarı görünümündedir.

Daha sonra kule olarak tanımlanan yapının alt yamacındaki dere yatağının doğusundan başlayıp kuzeydoğu-güneybatı istikametine ilerleyen teraslar tespit edilmiştir. Gps koordinatı alınıp fotoğraflaması yapılan teraslardan biri üzerinde ana kaya üzerinde içi ve dışı sıvalı 1.20 × $1.20 \mathrm{~m}$ ölçülerinde bir blok bulunmuştur. Ne amaçla kullanıldığı ve işlevi saptanamayan bu bloğun oturduğu ana kaya üzerinde blok düzeltilerek oturtulduğu tespit edilmiştir. Bloğun devamında küçük taş ve bloklarla ilerleyen teraslama duvarı tespit edilmiştir.

Bu teraslamanın üzerinde batıya doğru üstünde 3 , altında 3 adet teraslama izi güneybatıkuzeydoğu istikametinde 50-70 m boyunca topografya eğimi doğrultusunda ilerlemektedir. Teraslamalar birbirlerine paralel olarak yaklaşık 3-4 m mesafede hafif kavisli inşa edilmiştir.

Kule (gözetleme kulesi) olarak tanımlanan yapının ve diğer terasların altında güneydoğukuzeybatı istikametinde yaklaşık $50 \mathrm{~m}$ uzunlukta 2-3 sıra taş örgülü, çoğunlukla kaba, yer yer düzgün bloklarla yapılmış teras duvarları tespit edilmiştir. $4 \mathrm{~m}$ yukarıda diğer bir teras bulunmaktadır. Yoğun bitki örtüsü nedeniyle takip edilmesi son derece zor olan bu teras, bitki örtüsü, heyelan ve otoyoldan düşen taşların tahribatı nedeniyle belirsizdir. Teraslar, kuru ancak yoğun yağmurda oluşan dere yarı̆̆ının güneydoğusunda dikdörtgen ve iyi kesilmiş taşlarla sınırlandııımıştır.

Bununla birlikte Phaselis ile Tahtalı Dağ eteklerindeki gerek çiftlik yerleşimleri ve teraslamalar gerekse yol güzergahları ve savunma sistemleri büyük ölçüde farklı zamanlarda farkı

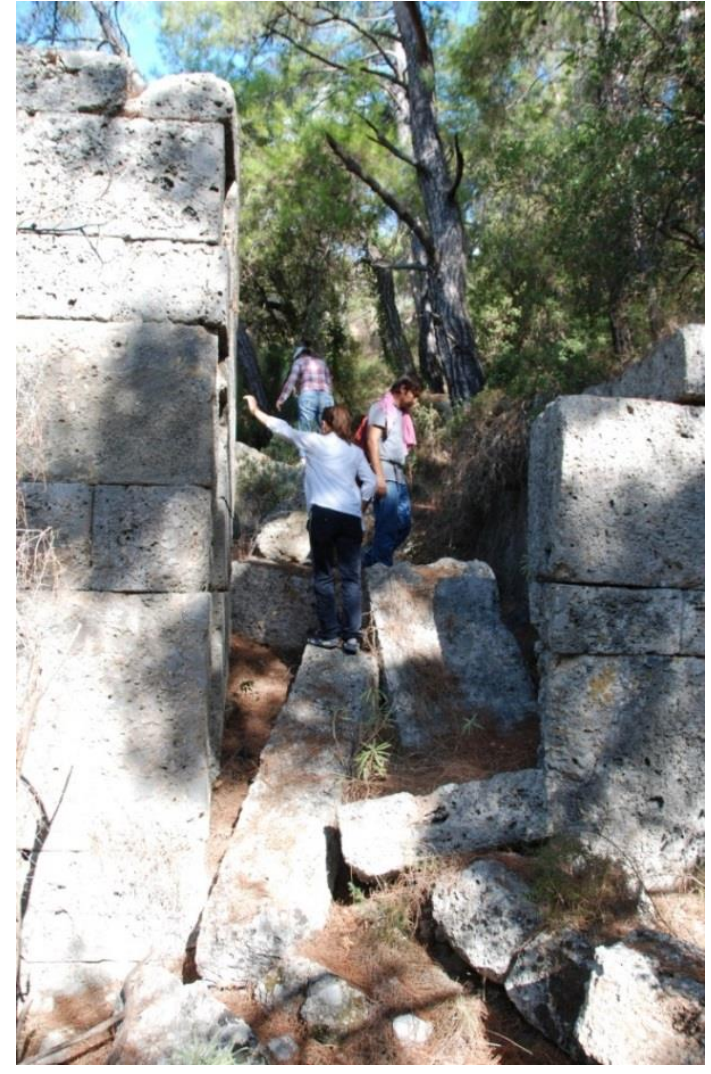

Phaselis, Hellenistik Kule Girişi mimari stil ve amaç doğrultusunda inşa edilmişlerdir. Bunlardan bazılarının kullanımı erken dönemlerden başlayarak ufak tamiratlarla geç antik çağa kadar görece sürdürülmüş olabilir. Buna Gökgür alanındaki kule örnek gösterilebilir. Diğer yandan farklı dönemlerde yani HelenistikRoma ve Geç Antikçağa ait örnekler de mevcuttur.

Phaselis-Teleferik Yolunun ortalarında Dudu Pınarı olarak adlandırılan mevkiinin yakınlarında Roma Dönemi'ne tarihlendirilebilecek bir kompleks tespit edilmiştir. Ekibimiz Yurt Yatağı olarak isimlendirilen söz konusu iskan alanına, Tahtalı Dağı'nın doğu eteklerindeki kulübesinde yaşayan Dudu Teyze'nin rehberliğinde götürülmüştür. Dudu Teyze'nin ikametgahının yaklaşık $2,5 \mathrm{~km}$ güneybatısında yer alan bu yerleşim son zamanlara kadar Yörüklerin yurtlandığı bir alan olarak da kullanıımışır. Kayalık pitoresk bir alanın hemen önündeki düzlük ve etrafındaki alanda yer 
alan birçok antik konutun Yörükler tarafından ya tekrar kullanıldığı ya da bu yapıların taşlarının kullanılarak basit, 3-4 m x 3-4 m'lik kare planlı, tek odalı, taş temel, ağaç direklerle yükseltilmiş, kısa süre kullanılan konutlar inşa edildiği tespit edilmiştir. Burada yer alan kayanın dibinden eskiden, yaz kış kurumayan bir pınarın varlığı ifade edilmiştir. Ancak son zamanlarda son derece yoğun bitki örtüsüyle kaplanan alanda söz konusu su kaynağını bulmak mümkün olmamıştır.

Yurt yatağının yak. $100 \mathrm{~m}$ güneyinde en az üç odalı tahkimli bir çiftlik yerleşimi konuşlandırımıştır. Pitoresk bir konuma sahip tahkimli çiftlik kompleksi doğuda Akdeniz, Çamyuva ve Kemer istikametine bakmaktadır. Büyük ölçüde çift sıra kesme taş bloklardan kuru taş tekniğiyle inşa edilen yapı son derece sağlam ve kaliteli bir işçiliğe sahiptir. Duvar kalınlığı 68-70 cm'dir. Odalardan birinin kapı sövesi in situ halinde olup güneye, denize doğru bakmaktadır. Çiftlik kompleksinin batısında hidrolik harçla sıvanmış bir kuyu bulunmaktadır. Kuyunun kuzey-güney çapı $170 \mathrm{~cm}$, doğu-batı çapı $172 \mathrm{~cm}$ ve derinliği $132 \mathrm{~cm}$ ölçülerindedir. Kuyunun üst örgüsü ve kapağı tahrip edilmiş ve içi doldurulmuştur. Kuyunun batı kenarı yer yer ana kayaya dayanmış olmakla birlikte diğer kenarları düzgün bir taş işçiliği sergilemektedir. Evin içinde ve çevresinde çatı kiremidi parçaları ve seramik buluntular mevcuttur. Lokal seramik parçaları olup çanak çömlekten şu an için tarihleme yapılabilecek bir parçaya rastlanılamamıştır. Ancak mimari yapı tekniği ve taş işçiliğine bakarak Roma Dönemi'ne ya da Hellenistik Dönem'e tarihlendirilebilir.

Çiftlik evinin daha sonradan da kullanılmış olabileceğine dair veriler mevcuttur. Ancak yapı son derece tahrip olduğu için gerek odaların ölçüleri gerekse planı şu an için çıkarılamamaktadır. Çiftlik evinin batı tarafında yapışık bir şekilde $45 \mathrm{~cm}$ duvar kalınlığına sahip $140 \mathrm{~cm}$ genişlik ve $420 \mathrm{~cm}$ boyunda tonozlu bir odacık yer almaktadır. Tonoz örgünün küçük bir bölümü in situ olarak korunabilmiştir, diğer bölümleri yıkılarak odacığın içine dökülmüştür. Su depolama amaçlı kullanımış olabileceği düşünülmektedir. Dudu Teyze'den yapının hemen yakınında eskiden bir dibek taşı/değirmen taşı (işlik) olduğu bilgisi alınmıştır. Ancak alanda yapılan incelemeler söz konusu buluntunun belgelenmesine imkan tanımamıştır. Alan her ne kadar orman ve maki örtüsü tarafından kaplanmış da olsa etrafında çok sayıda zeytin ve keçiboynuzu ağacı yer almaktadır.

Çiftlik kompleksinin etrafında $51 \mathrm{~cm}$ genişliğinde çift sıra kuru taş tekniğiyle inşa edilmiş kaliteli iş̧̧iliğe sahip bir duvar yer almaktadır. Bu duvarın çiftlik kompleksinin planına dahil olup olmadığı konusunda şu an için kesin bir yargıya varmak mümkün gözükmemektedir. Çiftlik kompleksinin yer aldığı yükseltinin etrafında da polygonal taş tekniğiyle büyük kayalar ve taşlardan düzgün bir şekilde işlenmiş bir tahkimat yer almaktadır. Tahkimat yapının güney yakası boyunca yak. $80 \mathrm{~m}$ izlenebilmektedir. Benzer durum tahkimatın köşe yaparak kuzeye doğru devam ettiği bölüm açısından da geçerlidir. Ancak son derece yoğun bitki örtüsü ve orman, surun takibini zorlaştırmaktadır. Ayrıca kuzey taraf yer yer Yörüklerin de kullandığı güzergahın üzerinde kaldığından taşları yerlerinden oynamış ve tahrip olmuş görünmektedir. Yapının gerekli fotoğraflama ve belgeleme işlemleri yapılmıştır.

Phaselis-Teleferik yolundan Tahtalı Dağı'na doğru devam eden yol yapımı sırasında tahrip edildiği tespit edilen, kesme taşlardan inşa edilmiş çiftlik evinin yer aldığı konum yakınlarında başlattığımız araştırma kuzeydoğu istikametinde devam ettirilmiştir. Tahtalı Dă̆ı'na doğru yükselen eğimli arazi topografyaya uygun bir şekilde kuzey-güney doğrultuda çok sayıda terasla kaplanmıştır. Birbirine paralel uzanan bu terasların arasında yer yer $6 \mathrm{~m}$ genişliğe sahip kuzeybatı-güneydoğu istikametinde ilerleyen bir yol saptanmıştır. 
Teraslar bu yolun kenarında tahkimli bir duvarla sonlanmakta ve birbirine paralel ilerleyen bu duvarın arasındaki yol yak. $500 \mathrm{~m}$ boyunca ilerlemektedir. Söz konusu yolun üzerinde çok sayıda kiremit, kaba kap parçaları ile çanak çömlek fragmanları yer almaktadır. Bunların çoğu kaba cidarlı olup devetüyü rengindedir. Bazılarına astar atılmıştır. İçlerinden bir bölümünün künk parçası olabileceği de düşünülmektedir.

Yolun güneyindeki istinat duvarına bitişik kesme taştan yapılma bir çiftlik evi tespit edilmiştir. Konutun kuzeybatı duvarında yer yer ana

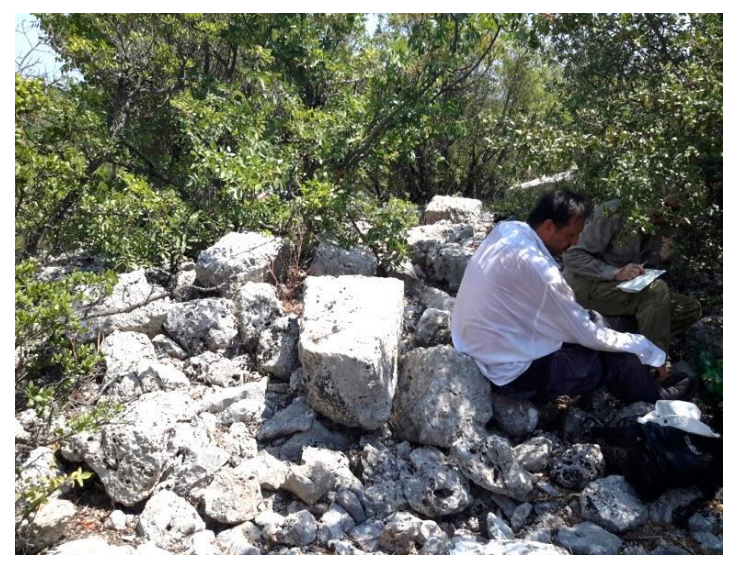

Roma Dönemi, Çiftlik Kompleksi Kalıntıları kaya kullanılmıştır. Ana kaya üzerinde de hatıl deliği olması muhtemel kare biçimli niş yer almaktadır. Çiftlik evi zaman içinde, doğa ve kaçak kazıcılar tarafından büyük ölçüde tahrip edilmiştir. Yapının içi ve çevresinde çatı kiremidi ile orta ve iyi düzey seramik fragmanları bulunmaktadır. Konutun planını çıkartmak kazı yapılmadan mümkün görülmemektedir. En az $10 \times 10 \mathrm{~m}$ ölçülerinde kare planlı olabileceği tespit edilmiştir.

Çiftlik evininden itibaren Tahtalı Dağı istikametine doğru ilerleyen yolu takibe devam edilmiştir. Takribi olarak 300 m sonra yol kaybedilmiş ve kireçtaşından kayalık bir tepenin önüne gelinmiştir. Tepenin güneyi derin bir vadiyle kesilmektedir. Son derece yoğun bitki örtüsüne sahip tepenin etrafı polygonal kireç taşlarıyla kuru duvar tekniğiyle örülmüştür. Tepenin çevresinde ve üzerinde seramik parçaları ve çatı kiremitleri görülmektedir. Duvar kalınlıkları 120 $\mathrm{cm}$ civarındadır ve iyi derecede tahkim edilmiştir. Tepenin hemen üzerinden Phaselis akropolis'i kuzey doğusunda Hellenistik kule, kuzeyinde ise Teleferik İstasyonu'nun hemen yanındaki Hellenistik kentçik görülebilmektedir. Sur duvarları tepeciği etraflıca çeviriyor olsa gerektir. Hem gözlem hem savunma hem de civarındaki bahçe kültürünü koruyucu bir fonksiyon içermiş olabilir. Zira konumu itibariyle Phaselis teritoryumunun ve Akdeniz'in çok geniş bir spektrumunu görebilmektedir. Ancak alanın son derece yoğun bitki örtüsü (çalı meşesi, sandal ağacı, çam, defne, maki ve değişik dikenli bitliklerle sarmaşıklar tarafından) ile kaplı olması nedeniyle sadece 70 m'lik kısmı gözlemlenip fotoğraflanabilmiştir.

Söz konusu tahkimat ya da üzerindeki yapılara ait herhangi bir plan çalışması şu an için mümkün görülmemektedir. Söz konusu tahkimatla bir gün önce bulduğumuz teraslar, su yolu ve kome (köy) olarak adlandırdığımız yerleşım bağlantı halindedir. Yapının kuzeydoğu eteklerinden, Phaselis istikametine doğru birçok teras saptanmış olup terasların topografyayı takip ederek kent istikametinde ilerledikleri belirlenmiştir. Terasların her birinin gps koordinatları alınmış, fotoğrafları çekilmiş ve tanımları yapılarak topografik haritamıza işlenmiştir. Tamamen balta girmemiş bir orman görünümünde olan bu alandaki teraslar üzerinde ayrıca birçok yabani zeytin ağacının varlığı gözlemlenmiştir.

Diğer bir gözetleme istasyonu ise Phaselis'e kuş bakışı bakan modern Antalya-Kumluca otoyolunun kenarından başlayarak yükselen kepezlerin hemen üzerinde keşfedilmiştir. Kepez üzerine çıkıldığında bent duvarının devamının güneye doğru devam ettiği ve burada üç tarafı yüksek tahkimli bir mevkiiyi koruduğu tespit edilmiştir. Tepenin üç tarafı derin kepezlerle çevrili olup tırmanılması pek de mümkün görülmemektedir. Burası Antalya-Kumluca otoyolundaki Phaselis sapağı tabelasının üzerindeki tepeden bir yandan Phaselis ile Antalya Körfezi'ni diğer 
yandan Gelidonya burnuna kadar Olympos ve hinterlandını kuşbakışı gören bir konumdadır. Tepe üzerinde çok sayıda yabani zeytin/delice (oleaster) ile çalı meşeleri göze çarpmaktadır. Gözetleme amacıyla kullanıldığı düşünülen bu alanda mimari kalıntıların yanı sıra çatı kiremitleri ile kilin kaba tarafından yapılma kalın cidarlı seramik parçaları yer almaktadır.

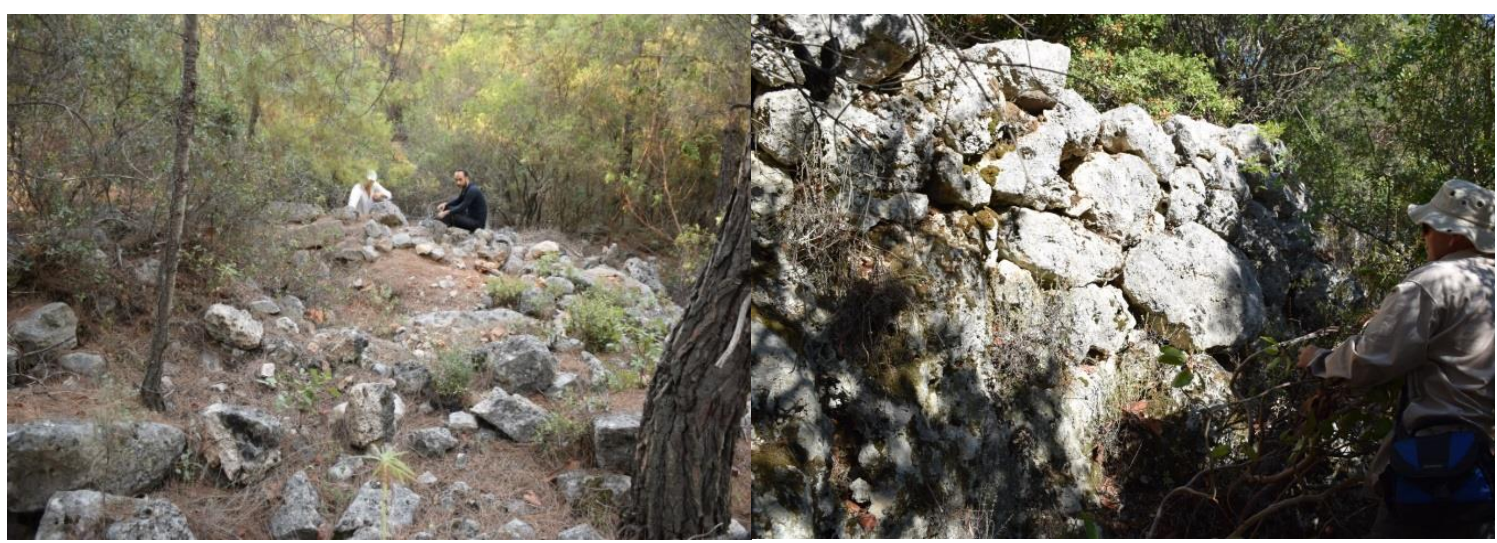

Çiftlik Kompleksi

Tahkimat Duvarı

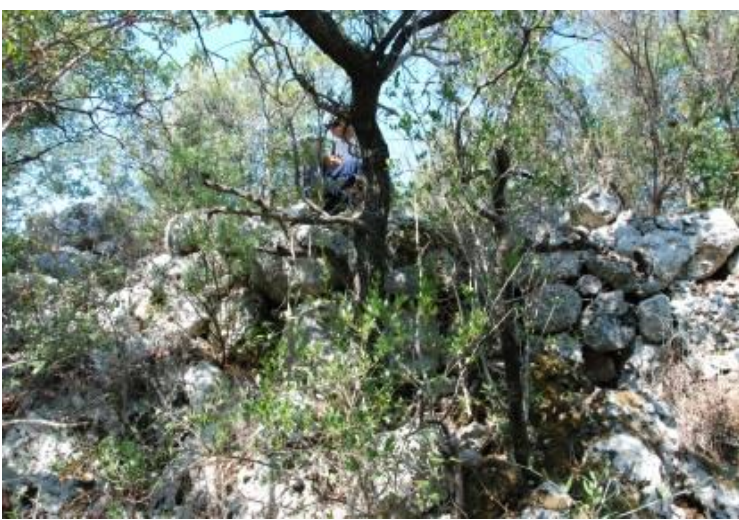

Tahkimat Duvarı

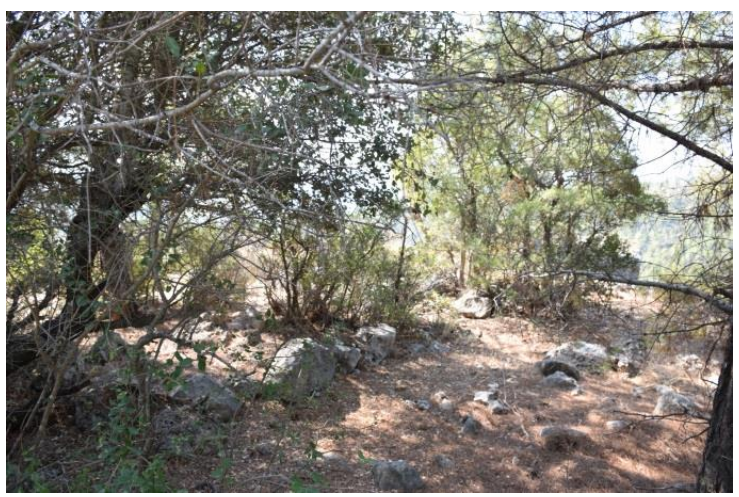

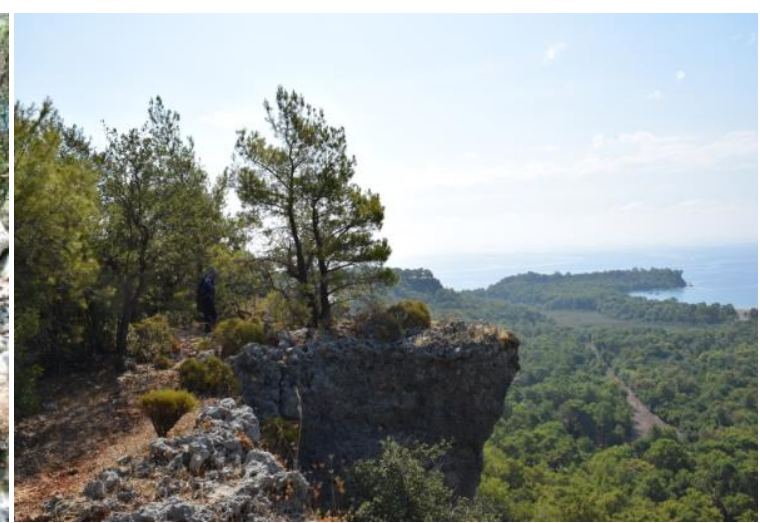

Tahkimli Gözetleme İstasyonu'ndan Phaselis'e Bakış

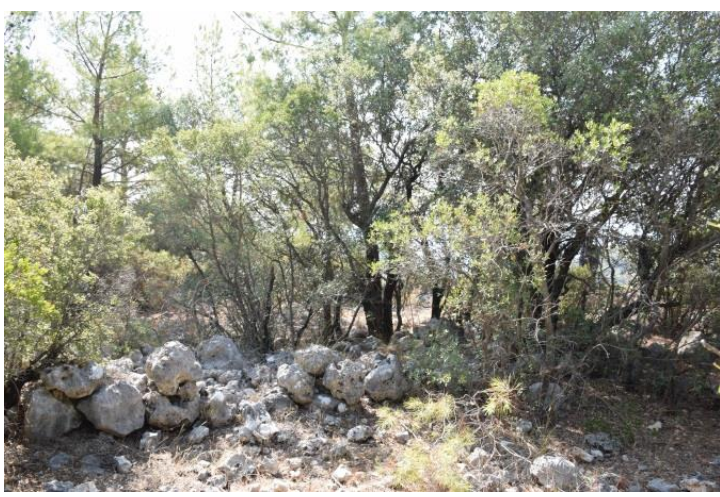

Tahkimli Gözetleme İstasyonu

Sonuç itibariyle Phaselis zengin ticari limanlara, tarım, bahçecilik ve hayvancılık yapmaya elverişli teraslara ve sulama sistemine sahip, refah düzeyi konumuyla ön plana çıkmaktadır. Bu yüzden Geç Klasik Dönem'den itibaren bu zenginlikten pay almak isteyen komşuları Mnaralıların 
akınlarına maruz kalmışlardır ${ }^{39}$. Kentin coğrafi konumu itibariyle aynı gün içinde Mnaralılar ana hedefleri olan Phaselis teritoryumunu yağmalayıp geri dönebilecek mesafede yer alıyorlardı ${ }^{40}$. Bu durum Phaselislileri gerek halihazırdaki durumları gerekse daha sonradan gerçekleştirilebilecek olası benzer durumlar için hazırlıkı olmaya itmiştir. Öyle ki, kentin yakın çevresinde yapılan alan arkeolojisi çalışmalarından elde edilen sonuçlar çerçevesinde üretim alanları ile ufak çaplı yerleşimlerin özellikle tahkimli konumlarda inşa edildiği ve etraflarının sağlam surlarla çevrildiği görülmektedir. Ayrıca söz konusu alanların yakınlarında Phaselis'in yerleşim, üretim ve ekonomi politikalarıla merkezi otorite tarafından mastır plan çerçevesinde aynı zamanda ve aynı planda inşa edilmiş birbirleriyle bağlantılı kule yapıları inşa edilmiştir. Bu kuleler bir yandan elde edilen ürünleri stoklarken diğer yandan diğer kuleler, gözetleme kuleleri, tahkimli yerleşimler ve ana kentle bağlantı içinde olacak şekilde birbirlerini gören pozisyonlarda konuşlandırılmıştır.

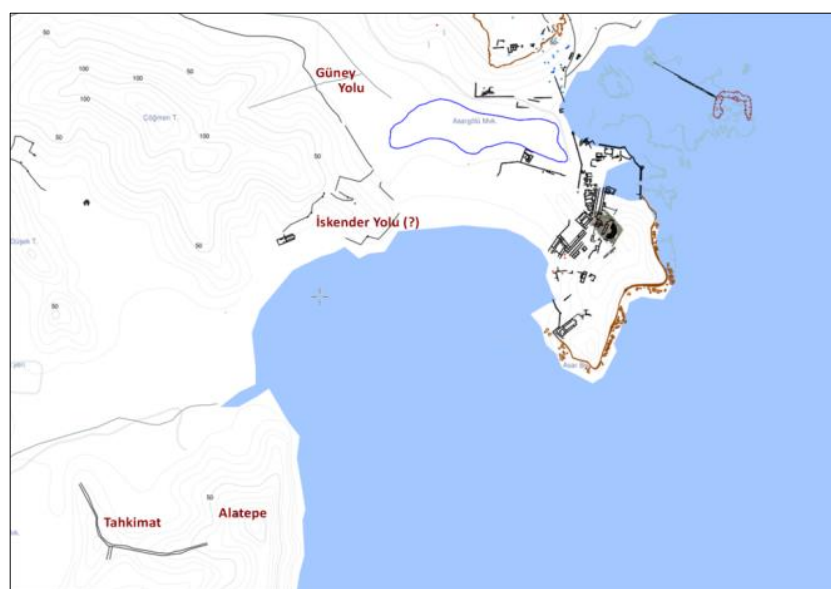

Phaselis-Tekirova Arası Güzergahlar

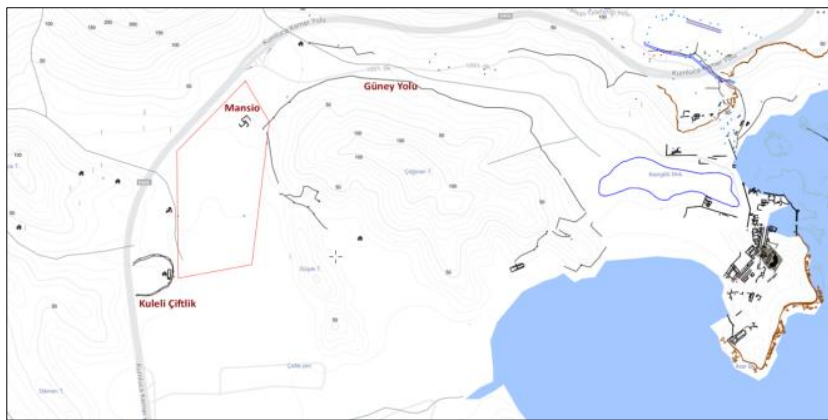

Çöğmen Tepe Etrafından Dolanan Güney Yolu

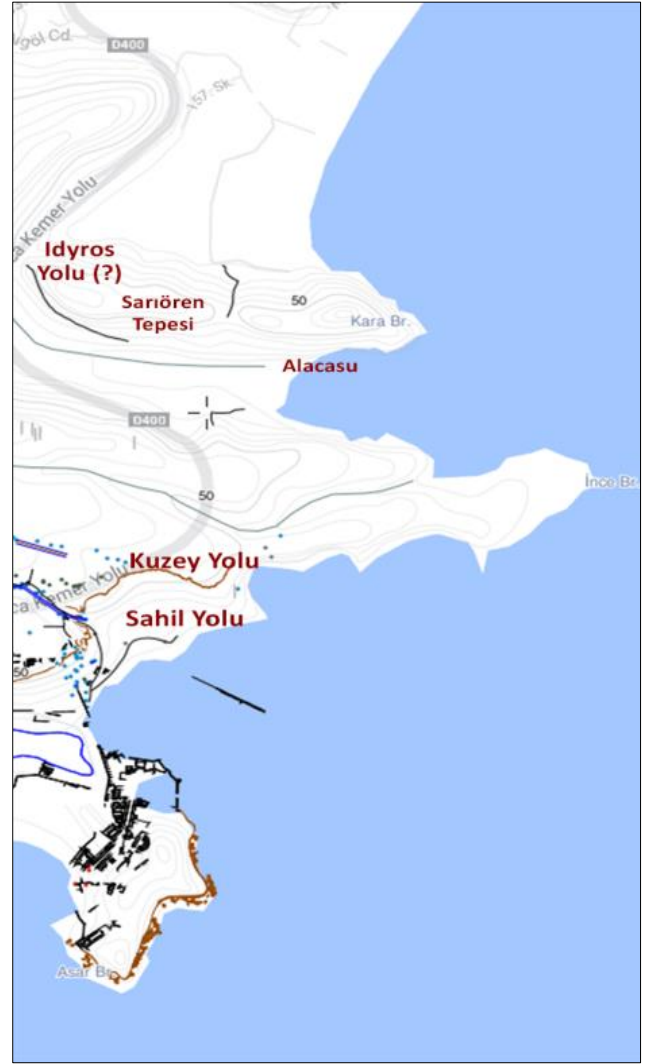

Phaselis-Çamyuva Arası Güzergahlar

Aralarında olası erken uyarı, haberleşme ve ortak savunma-yardımlaşma sistemleriyle de bağlı olsa gerektirler. Zira her ne kadar Phaselis'in yakın çevresindeki yerleşimlerle bağlantısını sağlayan güzergahların tamamı patikalar ve yaya yollarından ibaret olsa da ulaşım şebekesinin donatılmasında kentin ekonomik, sivil ve askeri operasyonlarına yönelik bir altyapının planlanması söz konusudur. Gene de bu durum Geç Klasik Dönem'de yeterli olmamış görünür ki, Mnaralıların yağma akınlarına karşı İskender'den yardım istemek zorunda kalmışlardır. İskender

39 Mnara'nın lokalizasyonu materyal kültür kalıntıları (yerleşim arkeolojisi, mimari yapıları ve zengin nekropolis'i) özelinde refah düzeyinin iyi derecede olduğu varsayılabilir. Bu zenginliği elde etmesindeki nedenlerden biri de -sarp bir topografyada tarımsal, ekonomik ve ticaret altyapısının oldukça sınırlı olduğu göz önünde tutulduğunda- yağmacılık olsa gerektir.

40 Anti 1923, 679 vd.; Baybutluoğlu 1993, 43; Şahin 2014, 300 vd. 
pek de kolay olmamak kaydıyla, ordusunun bir bölümünü bu işle görevlendirmiş ve iki gün boyunca birbiri ardına değişik intervallerle ve derecelerle devam eden hücumların ardından Mnaralıların tahkimli kayalığı ele geçirilmiştir ${ }^{41}$.

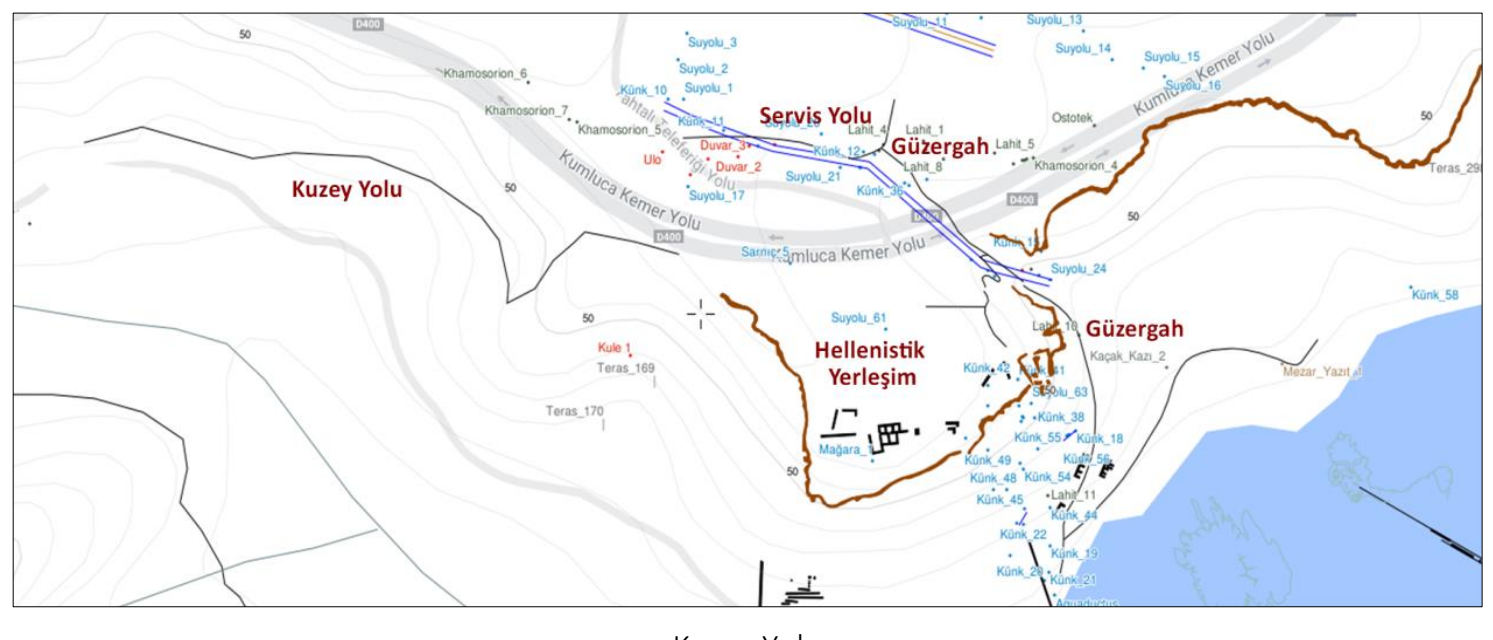

Kuzey Yolu

Araştırmamız kapsamında yapılan tetkikler özelinde Phaselis-Tekirova ve Çamyuva beldeleri arasında antik kaynaklarda geçen sahil yoluna ait kalıntılar belgelenmiştir. Bu güzergahlardan Tekirova istikametinde ilerleyen yolun geç antikçağda Alatepe üzerinde bir tahkimatla korunmuş olduğu ortaya çıkmıştır. Söz konusu güzergah Tekirova'dan devam ederek Stadiasmus Paterensis'te de ifade edildiği gibi Olympos'a (Korykos) doğru devam etmiş olsa gerektir.

Benzer durum Tekirova-Çamyuva arasındaki güzergah için de geçerlidir. Kentin kuzeydoğu nekropolis'inden ilerleyen güzergah topografyaya uygun bir şekilde büyük ölçüde sahili izleyerek Sarı̈ren Tepesi'ne kadar takip edilmiştir.

Söz konusu güzergahın buradan Idiros'a (Kemer), ardından da sahili takip ederek Perge'ye ulaşan İskender'in güzergahıyla ilişkilendirilebileceği görüşü ortaya çıkmıştır.

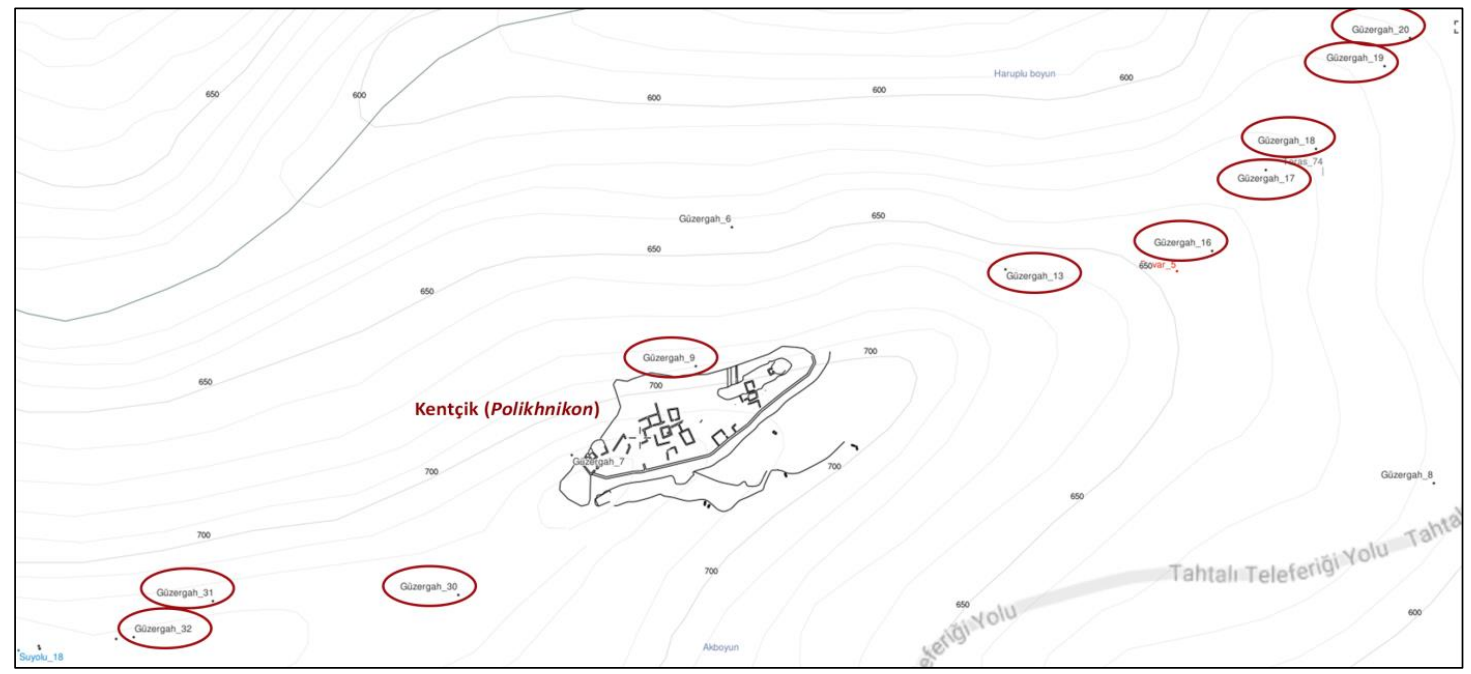

Kentçik ve Bağlantılı Güzergah

41 Diod. XVII. 28. 1-3; Arr. anab. I. 24. 5-6. 
Yol araştırmalarımız sırasında ayrıca kentin iç mahalleleriyle ve yakın çevresiyle iletişimini sağlayan değişik güzergahlar olduğu tespit edilmiştir. Bunlardan Phaselis -Tekirova arasında Çöğmen Tepe'nin etekleri ve etrafını dolaşarak iç kısımlardaki mahallelere ulaşımı sağlayan bir güzergah bulunmuş ve eskiden Rixos'a tahsis edilen parsele kadar (kırmızıyla çevrili alan) devam ettiği saptanmıştır.

Söz konusu alandaki ve modern AntalyaKumluca otoyolunun kuzeyindeki yapılaşmadan yola çıkarak bu güzergahın ayrıca kenti yakın çevresiyle bağlayan Tahtalı Dağı'na doğru ilerlemiş olma olasılığı bulunmaktadır. Ancak bu bağlantı noktası büyük bir ihtimalle modern Antalya -Kumluca yolu tarafindan tahrip edilmiştir. Benzer durum Phaselis-Çamyuva güzergahı için de geçerlidir. Kuzey yolu olarak adlandırdığımız bu güzergah da Phaselis Araştırma istasyonunun yakınlarından itibaren bir süre modern yola paralel ilerlemiş ancak bir süre sonra modern yolun dolgusu altında kalmıştır.

Ileride tekrar izlerini yakaladığımız ve Çamyuva önlerinde Sarıören Tepesi eteklerine kadar izlediğimiz yol modern yol tarafından son derece açık bir şekilde tahrip edilmiştir. Bu

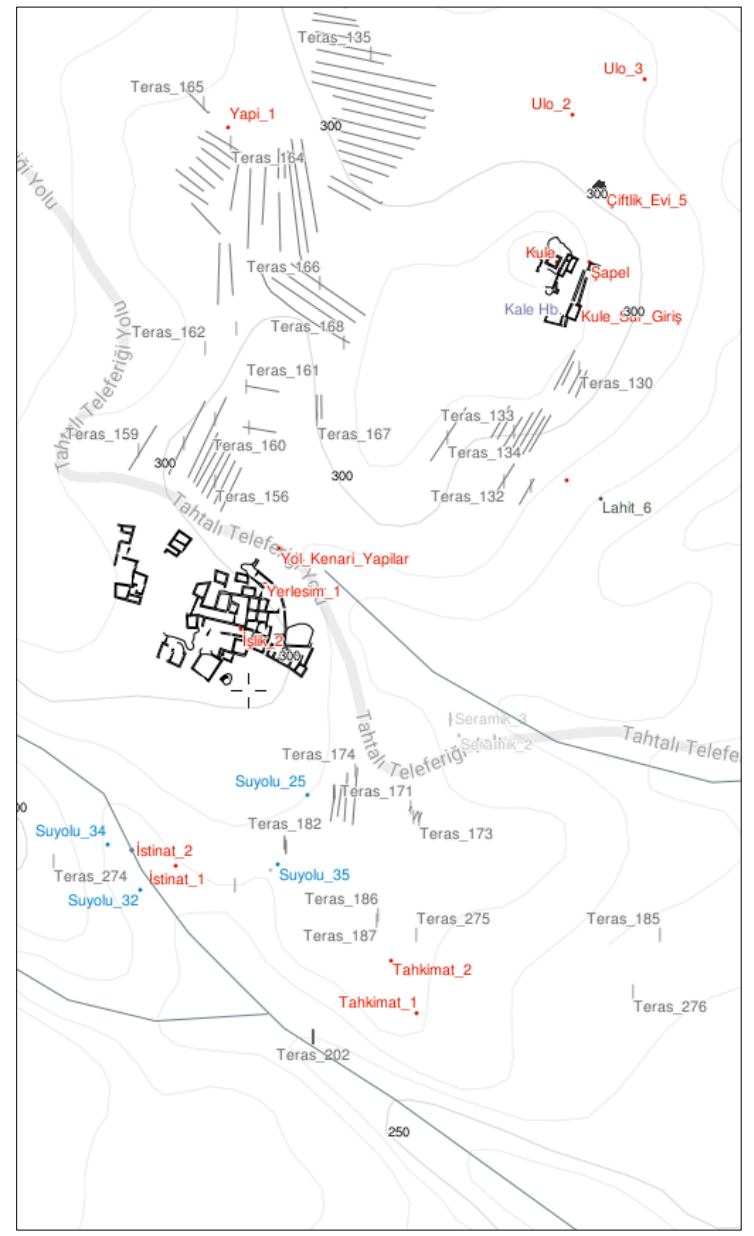

Yerleşke, Kule, Tahkimat ve Teraslar durum her iki iç güzergah açısından da aynıdır. Bu da antikçağdan itibaren Phaselis'in yakın çevresiyle bağlantısını sağlayan bu güzergahın antikitenin değişik zaman dilimlerinde ve periyotlarında kullanıldığına ve son olarak da günümüzde bu yolun bazı kısımlarının modern yolun altında kaldığına işaret etmektedir.

Phaselis-Tahtalı (Olympos) Dağı istikameti ise Hellenistik Yerleşke olarak adlandırılan ve dik kepezlerden kuzey kapısı yardımıyla Phaselis'e geçiş sağlayan güzergah üzerinden işlemiş olmalıdır. Kentin yakın çevresindeki bu üretim ağı Tahtalı Dağı'nın eteklerine kadar takip ettiğimiz ve yüzlercesini belgelediğimiz teraslar zinciriyle birbirine bağlıdır.

Bu güzergahların bir kısmı bu proje sayesinde bulunup belgelenmiştir. Bazen kente su sağlayan su sistemlerinin yanından ilerlemekte bazen de topografyaya uygun olarak patikalar şeklinde açılmaktadır.

Şimdiye kadar Phaselis teritoryumunda elde ettiğimiz bu sonuçlar, kent ile hinterlandı arasındaki yol ağını sadece yerleşim arkeolojisi perspektifinde ortaya çıkarmakla kalmamış, fakat aynı zamanda kartografik olarak da somutlaştırmaya başlamıştır. Veriler tarafımızdan oluşturulmuş olan envanterleme sistemine hem sınıflandırılarak hem de sayısallaştırılarak kaydedilmiş olup sonraki araştırmalar için temel teşkil edecek ve değerlendirmelere imkan sağlayacak düzeye 
getirilmiştir ${ }^{42}$. Her ne kadar şimdiye kadar yaptığımız yol ve savunma sistemleri araştırmaları ışığında önemli buluntular tespit edilmesine karşın sayısallaştırdığımız topografik haritalarda da görüldüğü üzere halen değişik intervaller özelinde izlenebilmektedir. Henüz başlangıç aşaması olarak kabul edeceğimiz bu tarz ön çalışmalar Phaselis yüzey araştırmaları çerçevesinde her geçen sene elde edeceğimiz yeni buluntular ve tespitlerle çeşitlenerek kentin antikçağ hinterlandına ait bilgilerimizin artmasına ve antik kent ile teritoryumunun daha iyi algılanmasına olanak sağlayacaktır.

Anti 1923

Arr. anab.

Arslan et al. 2013

Arslan - Tüner Önen 2014a

Arslan - Tüner Önen 2014b

Arslan - Tüner Önen 2014c

Arslan - Tüner Önen 2015

Arslan - Tüner Önen 2016a

Arslan - Tüner Önen 2016b

Arslan - Tüner Önen 2017a

\section{BIBBLIYOGRAFYA}

C. Anti, "Esplorazioni archeologiche nella Licia e nella Pamfilia". MonAL 29 (1923) 657-786.

(= Arrianus, Anabasis) Kullanılan Metin ve Çeviriler: Arrian, Anabasis Alexandri. Trans. P. A. Brunt, vol. I-II. Cambridge, Massachusetts - London 1976-1983 (The Loeb Classical Library). Arrian, Iskender'in Seferleri. Çev. M. Mete. İstanbul 2005.

M. Arslan, K. Demirtaş - N. T. Önen, "Phaselis ve Teritoryumu Yüzey Araştırması 2012". ANMED: Anadolu Akdenizi Arkeoloji Haberleri XI (2013) 224-229.

M. Arslan - N. T. Önen, "2012 Yılı Phaselis Antik Kenti ve Teritoryumu Yüzey Araştırması". AST XXXI/1 (2014) 78-89.

M. Arslan - N. T. Önen, "2013 Yılı Phaselis Antik Kenti ve Teritoryumu Yüzey Araştırması". AST: Araştırma Sonuçları Toplantısı XXXII/2 (2014) 289-300.

M. Arslan - N. T. Önen, "Phaselis ve Teritoryumu Yüzey Araştırması 2013". ANMED: Anadolu Akdenizi Arkeoloji Haberleri XII (2014) 189-195.

M. Arslan - N. T. Önen, "Phaselis ve Teritoryumu Yüzey Araştırması 2014". ANMED: Anadolu Akdenizi Arkeoloji Haberleri XIII (2015) 198-207.

M. Arslan - N. T. Önen, "2014 Yılı Phaselis Antik Kenti ve Teritoryumu Yüzey Araştırması". AST: Araştırma Sonuçları Toplantısı XXXIII/1 (2016) 69-80.

M. Arslan - N. T. Önen, "Phaselis ve Teritoryumu Yüzey Araştırması 2015". ANMED: Anadolu Akdenizi Arkeoloji Haberleri XIV (2016) 236-246.

M. Arslan - N. T. Önen, "2015 Yılı Phaselis Antik Kenti ve Teritoryumu Yüzey Araştırması". AST: Araştırma Sonuçları Toplantısı XXXIV/1 (2017) 355-368.

42 Kentin Tarihsel Coğrafi birikiminin açığa çıkarılması sırasında Phaselis ve yakın çevresinin yol ağı ve savunma sistemleri kuleler ve tahkimli yerleşimler antik yerleşimin temellendiği topografyanın sunduğu beşeri ve fiziki koşulları, alan arkeolojisi perspektifinde incelenmiştir. Elde edilen verilerle toprak üstü materyal kültür kalıntıları çok yönlü araştırma birikimi içinde analiz edilmiştir. Kayıt ve araştırma sistemindeki veritabanı uygulamalarımızda kullandığımız veri toplama araçları ve analiz yöntemleri olarak veri madenciliği ile veri görselleştirme tekniklerinden faydalanılmıştır. İşlenen bilgiler sayısallaştırılıp kente ait oluşturduğumuz bilgibelge merkezine dijital olarak aktarılmış, database'imize kaydedilmiş ve bu şekilde kent ve hinterlandının çok katmanlı kültür envanterinin oluşturulmasına yönelik bir temel atılmıştır. 
Arslan - Tüner Önen 2017b

Atilla 2018

Bayburtluoğlu 1993

Bayburtluoğlu 2004

Callatay 2017

Gürel 2016

Hdt.

Hurter - Pásztory 1984

IGCH

Kızgut 2017

Kuhrt 2007

Kürkçü 2016

Mergen 2015

Onur 2016

Salway 2007

Şahin 2014

Takmer - Tüner Önen 2007

Tüner Önen 2008

Tüner Önen - Akçay

Tüner Önen - Yılmaz 2015

Suet.

\section{Murat ARSLAN}

M. Arslan - N. T. Önen, "2016 Phaselis ve Teritoryumu Yüzey Araştırması". ANMED: Anadolu Akdenizi Arkeoloji Haberleri XV (2017) 211-221.

B. D. Atilla, Akdeniz'de Roma Devlet Arazileri'nin (Ager Publicus) Dağıtım ve Organizasyon Sistemi. Akdeniz Üniversitesi Sosyal Bilimler Enstitüsü. Yayımlanmamış Yüksek Lisans Tezi. (Bitirme Aşamasında) Antalya.

C. Bayburtluoğlu, "Siedlungen in Lykien". Akten Lykien II/2 (1993) 43-45.

C. Bayburtluoğlu, Lykia. İstanbul 2004.

F. Callatay, "Overstrikes on Pamphylia and Cilician Silver Staters (5th-4th c. BC)". Akmed ikinci Uluslararası Akdeniz Dünyasında Para Tarihi ve Nümismatik Kongresi. Yayınlanmamış Kongre Bildirisi. Ocak 2017, Antalya.

B. Gürel, "Phaselis Batı ve Kuzeybatı Nekropolis'leri". MJH VI/2 (2016) 279-297.

(= Herodotos, Historiae)

Kullanılan Metin ve Çeviri: The Persian Wars. With an English translation by A. D. Godley, vol. I-IV. Cambridge, Mass.-London $1920-2004^{12}$ (The Loeb Classical Library).

S. Hurter - E Pásztory, Archaischer Silberfund aus dem Antilibanon. Festschrift für Leo Mildenberg. Wetteren 1984.

Inventory of Greek Coin Hoards. New York.

i. Kızgut, "Antalya Tahtalı Dağı Çevresine Illişkin Yeni Bulgular ve Öneriler". Cedrus V (2017) 199-215.

A. Kuhrt, The Persian Empire A Corpus of Sources from the Achaemenid Period. Abingdon 2007.

M. Kürkçü, "Phaselis Hidrografi Sistemine Dair Değerlendirmeler". Phaselis II (2016) 103-121.

Y. Mergen, "2014 Yılı Çalışmaları Işı̆̆ında Phaselis Antik Kenti'nin Geç Antik ve Ortaçağ Mimarisi ile Kentsel Yapısı". Phaselis I (2015) 277-289.

F. Onur, "Stadiasmus Paterensis'te Yollar, Yerleşimler ve Terioryumlar". Eskiçağ Yazıları 8 (2016) 73-126.

B. Salway, "The perception and description of space in Roman itineraries". Şurada: Ed. M. Rathmann, Wahrnehmung und Erfassung geographischer Räume in der Antike. Mainz am Rhein (2007) 181-209.

S. Şahin, Stadiasmus Patarensis - Itinera Romana Provinciae Lyciae: Likya Eyaleti Roma Yolları. İstanbul 2014.

B. Takmer - N. Tüner Önen, Via Sebaste: Anadolunun En lyi Korunmuş Roma Yolu'nun Varsak'tan Geçen Güzergahı. Varsak Belediyesi Kültür Yayınları 2. İstanbul 2007.

N. Tüner Önen, Phaselis Antik Kenti ve Teritoryumu. Akdeniz Üniversitesi Sosyal Bilimler Enstitüsü. Yayımlanmamış Doktora Tezi.

N. Tüner Önen - A. Akçay "Phaselis Kentinin Su Teminine Illişkin Gözlemler ve Dijital Epigrafi Çalışmaları”. MJH IV/2 (2014) 279-292.

N. Tüner Önen - F. Yılmaz "A New Athena Polias Votive Inscription from the Phaselis' Acropolis". Adalya XVIII (2015) 121-132.

(= Suetonius, De Vitae Caesarum) Kullanılan Metin ve Çeviri: The Lives of the Caesars. Edited and translated by J. C. Rolfe I-II. Cambridge, Mass.London $2001^{4}$ (The Loeb Classical Library). 